\title{
Telmisartan directly ameliorates the neuronal inflammatory response to IL-1 $\beta$ partly through the JNK/C-Jun and NADPH oxidase pathways
}

Tao Pang ${ }^{*}$, Juan Wang, Julius Benicky, Enrique Sánchez-Lemus and Juan M Saavedra

\begin{abstract}
Background: Blockade of angiotensin II type $1\left(\mathrm{AT}_{1}\right)$ receptors ameliorates brain inflammation, and reduces excessive brain interleukin-1 beta (IL-1 $\beta$ ) production and release from cortical microglia. The aim of this study was to determine whether, in addition, $\mathrm{AT}_{1}$ receptor blockade directly attenuates IL-1 $\beta$-induced inflammatory responses in neuronal cultures.
\end{abstract}

Methods: SK-N-SH human neuroblasts and primary rat cortical neurons were pretreated with telmisartan followed by exposure to IL-1 $\beta$. Gene expression was determined by reverse transcriptase (RT)-PCR, protein expression and kinase activation by western blotting, NADPH oxidase activity by the lucigenin method, prostaglandin $E_{2}\left(\mathrm{PGE}_{2}\right)$ release by enzyme immunoassay, reactive oxygen species (ROS) generation by the dichlorodihydrofluorescein diacetate fluorescent probe assay, and peroxisome proliferator-activated receptor gamma (PPARY) involvement was assessed with the antagonists GW9662 and T0070907, the agonist pioglitazone and the expression of PPARy target genes $A B C G 1$ and CD36.

Results: We found that SK-N-SH neuroblasts expressed AT 1 but not $A T_{2}$ receptor mRNA. Telmisartan reduced IL-1 $\beta$ induced cyclooxygenase-2 (COX-2) expression and $\mathrm{PGE}_{2}$ release more potently than did candesartan and losartan. Telmisartan reduced the IL-1 $\beta$-induced increase in IL-1R1 receptor and NADPH oxidase-4 (NOX-4) mRNA expression, NADPH oxidase activity, and ROS generation, and reduced hydrogen peroxide-induced COX-2 gene expression. Telmisartan did not modify IL-1 $\beta$-induced ERK1/2 and p38 mitogen-activated protein kinase (MAPK) phosphorylation or nuclear factor-KB activation but significantly decreased IL-1 $\beta$-induced c-Jun N-terminal kinase (JNK) and c-Jun activation. The JNK inhibitor SP600125 decreased IL-1 $\beta$-induced PGE 2 release with a potency similar to that of telmisartan. The PPARY agonist pioglitazone reduced IL-1 $\beta$-induced inflammatory reaction, whereas telmisartan did not activate PPARY, as shown by its failure to enhance the expression of the PPARY target genes ABCG1 and CD36, and the inability of the PPARY antagonists GW9662 and T0070907 to modify the effect of telmisartan on COX-2 induction. The effect of telmisartan on IL-1 $\beta$-stimulated COX-2 and IL-1R1 mRNA expression and ROS production was replicated in primary rat cortical neurons.

Conclusions: Telmisartan directly ameliorates IL-1 $\beta$-induced neuronal inflammatory response by inhibition of oxidative stress and the JNK/c-Jun pathway. Our results support the hypothesis that $\mathrm{AT}_{1}$ receptor blockers are directly neuroprotective, and should be considered for the treatment of inflammatory conditions of the brain.

Keywords: Angiotensin II AT 1 receptor blockers, SK-N-SH neuroblasts, Cortical neurons, Neuronal inflammation, Neuroprotection, Oxidative stress, COX-2, PGE 2 release, JNK activation, IL-1 $\beta$ neurotoxicity

\footnotetext{
* Correspondence: pangt@mail.nih.gov

Division of Intramural Research Programs, National Institute of Mental Health, National Institutes of Health, Department of Health and Human Services, Section on Pharmacology, NIMH, NIH, DHHS, 10 Center Drive, Bldg. 10, Room \# 2D-57, Bethesda, MD 20892, USA
} 


\section{Background}

Interleukin-1 beta (IL-1 $\beta$ ) is a neuromodulator primarily synthesized by microglia, with multiple physiological roles including regulation of sleep, memory, synaptic plasticity, and the innate immune response [1-4]. IL-1 $\beta$ is also a powerful inflammatory cytokine [4]. Excessive IL-1 $\beta$ production and release injures neurons, and is considered a major factor in the development and progression of neurodegenerative disorders, stroke, brain injury, and depression [5-10]. At present, there are no effective treatments to control excessive neuroinflammation [11]. The search for novel, safe, and effective central anti-inflammatory drugs, including those directly antagonizing the IL-1 $\beta$-induced neuronal injury $[12,13]$, is therefore of major interest.

The brain renin-angiotensin system (RAS) has emerged as a novel therapeutic target. Increased RAS activation, leading to excessive $\mathrm{AT}_{1}$ receptor stimulation, is a major factor in the development and progression of brain inflammation as a consequence of central or systemic infection [14,15], heart failure [16], and aging [17]. In turn, administration of $\mathrm{AT}_{1}$ receptor blockers (ARBs) decreases brain inflammation and is neuroprotective [18,19]. Therapeutic effects of ARBs have been shown in rodent models of systemic inflammation [15], hypertension, cerebral ischemia and stroke [20-27], intracerebral hemorrhage [28], multiple sclerosis [29], Parkinson's disease (PD) [30,31], Alzheimer's disease (AD) [32,33], and aging [17]. The neuroprotective effect of ARBs, as reported in rodent models, is partly direct and not entirely dependent on its effects on cardiovascular regulation $[15,22,23,32,33]$. This neuroprotective effect has also been shown in vitro using neuronal cultures [15,34-36].

To further clarify the mechanisms of the direct antiinflammatory effects of ARBs in neuronal targets, we studied the effects of ARBs in a well-characterized human neuronal system widely used as an in vitro model of neuronal injury, the SK-N-SH neuroblastoma cell line $[37,38]$. In particular, we focused on telmisartan as an ARB prototype because of its reported pleiotropic antiinflammatory effects as an $\mathrm{AT}_{1}$ receptor antagonist and a peroxisome proliferator-activated receptor gamma (PPAR $\gamma$ ) agonist [23,32,39-41]. We investigated whether telmisartan ameliorates the inflammatory response to IL-1 $\beta$ in SK-N-SH neuroblasts and what are the mechanisms involved in these effects, and we compared the effects of telmisartan in SK-N-SH neuroblasts with those in rat primary cortical neurons.

\section{Methods}

\section{Materials and reagents}

Cell-culture media and supplements were obtained from Invitrogen (Carlsbad, CA, USA). Recombinant rat IL-1 $\beta$ was purchased from R\&D Systems (Minneapolis, MN, USA). Telmisartan, losartan, CGP 42112, PD 123319, pioglitazone, diphenyleneiodonium chloride (DPI), SP600125, GW9662 and T0070907 were all purchased from Sigma-Aldrich (St. Louis, MO, USA). Candesartan was a kind gift from Astra-Zeneca (Mőlndal, Sweden). Angiotensin II was purchased from Bachem (Torrance, CA, USA). Primers for real-time PCR were synthesized by BioServe (Beltsville, MD, USA). SYBR Green PCR Master Mix for qPCR was purchased from Applied Biosystems (Foster City, CA, USA). The remaining reagents for RNA isolation and reverse transcription were from Invitrogen. Primary antibodies used for western blot analysis were: rabbit polyclonal anti-nuclear factor-kappa B (NF-kB)-p65 antibody (1:2000, Millipore, Billerica, MA, USA); mouse polyclonal anti-cyclooxygenase-2 (COX-2) (1:1000, Cayman Chemical, Ann Arbor, MI, USA); rabbit anti-phospho-p38 mitogen-activated protein kinase (MAPK) (1:1000), rabbit anti-phosphoextracellular signal-regulated kinases (ERK)1/2 (1:1000), rabbit anti-phospho-JNK (1:1000), rabbit anti-phospho-c -Jun (1:1000), rabbit anti-IкB- $\alpha$ (1:1000), rabbit anti- $\beta$ actin (1:1000), and rabbit anti-histone H4 (1:1000), all from Cell Signaling Technology (Danvers, MA, USA). Secondary horseradish peroxidase-conjugated antibodies for western blot analysis were: donkey anti-rabbit IgG (1:5000, Amersham BioSciences, Piscataway, NJ, USA) and goat anti-mouse IgG (1:10,000, Jackson ImmunoResearch, West Grove, PA, USA). Protease inhibitor cocktail and SuperSignal West Dura Substrate for chemiluminescent detection were purchased from Thermo Fisher Scientific (Pittsburg, PA, USA). All other chemicals were obtained from Sigma-Aldrich unless otherwise stated.

\section{SK-N-SH neuroblast culture}

Human SK-N-SH neuroblasts were obtained from the American Type Culture Collection (HTB-11, Rockville, MD, USA) and grown in MEM with Earle's salts and HEPES, supplemented with $10 \%$ fetal bovine serum and $100 \mathrm{U} / \mathrm{ml}$ penicillin/streptomycin. Cells were cultured at $37^{\circ} \mathrm{C}$ in a humidified atmosphere of $5 \% \mathrm{CO}_{2} / 95 \%$ air until they reached $80 \%$ confluence, then confluent monolayers were passaged routinely by trypsinization. Cells between passages 3 and 10 were used in this study, and before each experiment, they were starved overnight in a serum-free medium.

\section{Primary rat cortical neuron culture}

All animal care and experimental procedures in the present study were approved by the National Institute of Mental Health Animal Care and Use Committee (Bethesda, MD, USA). All efforts were made to minimize the number of animals used and their suffering 
(National Institutes of Health Guide for the Care and Use of Laboratory Animals, Publication number 80-23, received 1996). Primary cortical neuron cultures were obtained from fetal Sprague-Dawley rats (Charles River Laboratories, Wilmington, MA USA) at embryonic day 18 (E18) [42]. Fetal cerebral cortices were collected and placed in ice-cold Hank's balanced salt solution. After removal of the meninges, the cortices were dispersed into the same buffer containing $0.25 \%$ trypsin, and digested for 15 minutes at $37^{\circ} \mathrm{C}$. Trypsin digestion was stopped by adding a two-fold volume of DMEM, supplemented with $10 \% \mathrm{FBS}$ and $0.1 \mathrm{mg} / \mathrm{ml}$ DNase I. After gentle trituration, digested tissues were separated by centrifugation at $200 \times g$ for 5 minutes. The cell pellets were resuspended in complete Neurobasal culture medium supplemented with $2 \% \mathrm{~B} 27$ and $0.5 \mathrm{mmol} / \mathrm{l}$ GlutaMax. After filtration through a $70 \mu \mathrm{m}$ cell restrainer (BD Falcon, Vernon Hills, IL, USA), cells were plated at a density of $1 \times 10^{6}$ cells $/ \mathrm{ml}$ onto poly-D-lysine coated plates (Becton Dickinson and Co., Franklin Lakes, NJ, USA). Cultures were incubated in a humidified atmosphere of $5 \% \mathrm{CO}_{2} / 95 \%$ air at $37^{\circ} \mathrm{C}$. Only mature cultures (10-14 days in vitro) were used in this study. Immunocytochemical validation with anti-microtubuleassociated protein 2 (MAP-2) antibody and 4,6-diamidino-2-phenylindole (DAPI) showed that more than $95 \%$ of the cells in the culture system were neurons (data not shown).

\section{Drug treatment}

The cells were pre-incubated for 2 hours with telmisartan, candesartan, losartan, CGP 42112, PD 123319, DPI, SP600125, pioglitazone, T0070907, GW9662, or vehicle before exposure to IL-1 $\beta$. Most of the experiments were performed with the maximum stimulatory concentration of $10 \mathrm{ng} / \mathrm{ml} \mathrm{IL}-1 \beta$, and the exposure times were 2 hours for ROS determination, 3 hours for RT-PCR analysis, and 24 hours for COX-2 protein and $\mathrm{PGE}_{2}$ determinations. The SK-N-SH neuroblasts were incubated with $100 \mu \mathrm{mol} / \mathrm{l} \mathrm{H}_{2} \mathrm{O}_{2}$ for 3 hours to determine the protective effect of telmisartan. Activation of MAPKs, c-Jun, and $\mathrm{NF}-\mathrm{KB}$ was determined by western blotting at various time intervals up to 2 hours. All concentrations used and time intervals are indicated in the figure legend for each particular experiment. All drugs were initially prepared as 1000-fold concentrated stock solutions, and were added directly into the cell-culture medium. Telmisartan, DPI, SP600125, pioglitazone, T0070907, and GW9662 were dissolved in dimethyl sulfoxide (DMSO). The final concentration of DMSO in experimental conditions was $0.1 \%$. Candesartan was initially dissolved in $0.1 \mathrm{~mol} / \mathrm{l} \mathrm{Na}_{2} \mathrm{CO}_{3}$, and further diluted to stock concentration with isotonic saline, at a final $\mathrm{pH}$ of 7.5 to 8.0. All other drugs were dissolved in isotonic saline. Control cells were treated with the corresponding vehicle in all experiments.

\section{Real-time PCR}

Total RNA was isolated using TRIzol reagent followed by purification using an RNeasy Mini Kit (Qiagen, Valencia, CA, USA) in accordance with the manufacturer's instructions. Synthesis of complementary DNA (cDNA) was performed with $0.6 \mu \mathrm{g}$ of total RNA and SuperScript III first-Strand Synthesis Kit (Invitrogen, Carlsbad, CA, USA). Quantitative real-time PCR was performed on DNA Engine Opticon $^{\text {tw }}$ (MJ Research, Waltham, MA) with SYBR Green PCR Master Mix. PCR was performed in a $20 \mu \mathrm{l}$ reaction mixture containing $10 \mu \mathrm{l}$ SYBR Green PCR Master Mix, $2 \mu \mathrm{l}$ cDNA and $0.3 \mu \mathrm{mol} / \mathrm{l}$ of each primer for a specific target (Table 1). The amplification conditions consisted of 1 denaturation/activation cycle at $95^{\circ} \mathrm{C}$ for 10 minutes, followed by 40 to 45 cycles at $95^{\circ} \mathrm{C}$ for 15 seconds and $60^{\circ} \mathrm{C}$ for 60 seconds. Serial dilutions of cDNA from the same source as samples were used to obtain a standard curve. The individual targets for each sample were quantified by determining the cycle threshold $(\mathrm{Ct})$ and by comparison with the standard curve. The relative amount of the target mRNA was normalized to the level of GAPDH mRNA.

\section{Western blotting}

For the determination of NFKB-p65 nuclear translocation, nuclear protein extracts were prepared using $\mathrm{Nu}$ clear Extraction Kit (Pierce, Rockford, IL, USA) in accordance with the manufacturer's instructions. For other proteins, the whole-cell lysates were prepared in Tris-Glycine SDS Sample Buffer (Invitrogen). The protein extracts were separated by electrophoresis on $10 \%$ SDS-PAGE gels and transferred onto polyvinylidene fluoride (PVDF) membranes. The membranes were blocked for 1 hour and incubated overnight at $4^{\circ} \mathrm{C}$ with the primary antibodies, followed by washing and exposure to secondary antibodies for 1 hour at room temperature. The membranes were exposed to SuperSignal West Dura Substrate for chemiluminescent detection.

\section{Measurement of reactive oxygen species}

The levels of intracellular ROS were determined by the change in the fluorescence resulting from the oxidation of the fluorescent probe $\mathrm{H}_{2}$ DCFDA using OxiSelect ${ }^{\mathrm{tm}}$ ROS Assay Kit (Cell Biolabs, San Diego, CA, USA) in accordance with the manufacturer's instructions. After preincubation with telmisartan or DPI, the cells were loaded with $\mathrm{H}_{2}$ DCFDA for 30 minutes at $37^{\circ} \mathrm{C}$ and exposed to IL- $1 \beta$ for an additional 2 hours. The level of fluorescence, corresponding to intracellular ROS, was determined using a plate reader (VICTOR3; Perkin-Elmer, Torrance, CA, USA) with $485 \mathrm{~nm}$ excitation and $535 \mathrm{~nm}$ emission filters. 
Table 1 List of PCR primers used in the study

\begin{tabular}{|c|c|c|c|}
\hline Gene & Accession number & Forward primer $\left(5^{\prime} \rightarrow 3^{\prime}\right)$ & Reverse primer $\left(5^{\prime} \rightarrow 3^{\prime}\right)$ \\
\hline $\mathrm{hAT}_{1}$ & $\mathrm{~S} 77410$ & ACCGCCCCTCAGATAATGTAAG & TGAAGTGCTGCAGAGGAATGTT \\
\hline hCOX-2 & NM_000963 & GATTGCCCGACTCCCTTGG & AACTGATGCGTGAAGTGCTG \\
\hline hGAPDH & NM_002046 & CCCATCACCATCTTCCAGGAG & GTTGTCATGGATGACCTTGGCC \\
\hline hlkB-a & NM_020529 & CGGACTGCCCTTCACCTC & ACATCAGCCCCACACTTCAA \\
\hline hIL-1R1 & NM_000877 & AGAGGAAAACAAACCCACAAGG & CTGGCCGGTGACATTACAGAT \\
\hline hNOX-1 & NM_013955 & ATCACAACCTCACCTTCCAC & ATAGGCTGGAGAGAATGGA \\
\hline hNOX-2 & NM_000397 & CCCTTGGCACTGCCAGTGAAGAT & CAATCCCTGCTCCCACTAACATCA \\
\hline hNOX-4 & NM_016931 & GGATCACAGAAGGTTCCAAGCAG & GCAGCCACATGCACGCCTGAGAA \\
\hline hNOX-5 & NM_024505 & ATCAAGCGGCCCCCTIITITCAC & CTCATTGTCACACTCCTCGACAGC \\
\hline $\mathrm{rAT}_{1 \mathrm{~A}}$ & NM_030985 & AGCCTGCGTCTTGTTITGAG & GCTGCCCTGGCTTCTGTC \\
\hline rCOX-2 & AF233596 & CGGAGGAGAAGTGGGGTTAAGGAT & TGGGAGGCACTTGCGTTGATGG \\
\hline rGAPDH & NM_017008 & ATGACTCTACCCACGGCAAG & TGGAAGATGGTGATGGGTTT \\
\hline rlL-1R1 & NM_013123 & TGAATGTGGCTGAAGAGCAC & CTTCCATCGTCTCATTCCGT \\
\hline
\end{tabular}

h, human; r, rat.

For $\mathrm{AT}_{1}$ receptor mRNA expression, the products of $\mathrm{PCR}$ amplification were separated on $3 \%$ agarose gel and visualized with ethidium bromide to verify the size of amplicon.

\section{Prostaglandin $\mathrm{E}_{2}$ measurement by enzyme immunoassay} $\mathrm{PGE}_{2}$ release was determined in cells culture medium by enzyme immunoassay (EIA) ( $\mathrm{PGE}_{2}$ EIA Kit; Cayman Chemical) in accordance with the manufacturer's instructions.

\section{NADPH oxidase activity assay}

The lucigenin method was used to determine NADPH oxidase activity in SK-N-SH cells. Cells were collected by scraping, and pelleted by centrifugation at $500 \times g$ for 5 minutes. The pellets were resuspended and homogenized in ice-cold buffer containing $50 \mathrm{mmol} / \mathrm{l}$ Tris, $\mathrm{pH} 7.4,1 \mathrm{mmol} / \mathrm{l}$ EDTA, $1 \mathrm{mmol} / \mathrm{l}$ DTT, $0.5 \mathrm{mmol} / \mathrm{l}$ phenylmethylsulfonyl fluoride (PMSF) and $1 \times$ protease inhibitor cocktail. The crude membrane fraction was pelleted by centrifugation at $16,000 \times g$ for 90 minutes at $4^{\circ} \mathrm{C}$, and the pellets were resuspended in $200 \mu \mathrm{l}$ of assay buffer containing $8 \mathrm{mmol} / \mathrm{l}$ sodium phosphate, pH 7.4, $140 \mathrm{mmol} / \mathrm{l} \mathrm{NaCl}, 10 \mathrm{mmol} / \mathrm{l} \mathrm{KCl}$, $2 \mathrm{mmol} / \mathrm{l} \mathrm{MgCl}_{2}, 50 \mathrm{mmol} / \mathrm{l}$ triethanolamine, $1 \mathrm{mmol} / \mathrm{l}$ DTT, and $1 \times$ protease inhibitor cocktail. The total protein concentration was determined by the Bradford assay and adjusted to $1 \mathrm{mg} / \mathrm{ml}$. An aliquot $(200 \mu \mathrm{l})$ of protein sample (100 $\mu \mathrm{g}$ of membrane proteins) were incubated in the presence of $5 \mu \mathrm{mol} / \mathrm{l}$ lucigenin and $100 \mu \mathrm{mol} / \mathrm{l} \mathrm{NADPH}$. The luminescence was monitored at 2-minute intervals using a plate reader (VICTOR3; Perkin-Elmer) to determine relative changes in NADPH oxidase activity.

Ang II measurement by enzyme immunoassay

Ang II concentration in the cell-culture medium was measured using a commercial kit (Ang II EIA Kit;
Cayman Chemical) following the manufacturer's instructions. The limit of sensitivity of the assay was $1.5 \mathrm{pg} / \mathrm{ml}$.

\section{Statistical analysis}

Statistical significance was determined using GraphPad Prism 5 Software (GraphPad Software, San Diego, CA, USA). Multiple group comparisons were performed by one-way ANOVA followed by Newman-Keuls Post test. Differences were considered significant at $P<0.05$. Values are expressed as the mean \pm SEM.

\section{Results}

Dose response and time course of interleukin- $1 \beta$-induced neuronal inflammatory response

Incubation of SK-N-SH neuroblasts in the presence of IL-1 $\beta$ induced COX-2 mRNA expression in a dosedependent and time-dependent manner (Figure 1A,B). Maximum stimulation of COX-2 mRNA was obtained

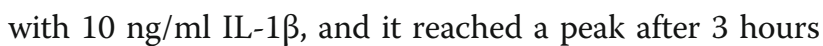
of exposure (Figure $1 \mathrm{~A}$ and $1 \mathrm{~B}$ ). Thus, this dose of IL-1 $\beta$ was selected for all subsequent experiments.

\section{Angiotensin II receptor type 1 blockade reduces} interleukin-1 $\beta$-induced cyclooxygenase- 2 expression and prostaglandin $\mathrm{E}_{2}$ release

Telmisartan, candesartan and losartan reduced IL-1 $\beta$ induction of COX-2 mRNA with equal potency (Figure 1C). All three ARBs dose-dependently reduced IL- $1 \beta$-induced $\mathrm{PGE}_{2}$ release, but telmisartan was significantly more potent than candesartan or losartan (Figure 1D). Telmisartan dose-dependently decreased IL- $1 \beta$-induced COX- 2 mRNA expression (Figure 1E) and COX-2 protein expression (Figure 1F). 
A

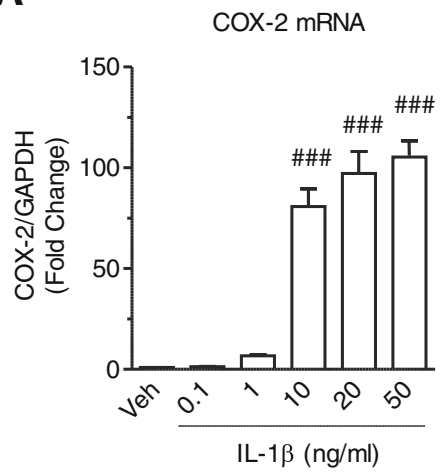

C

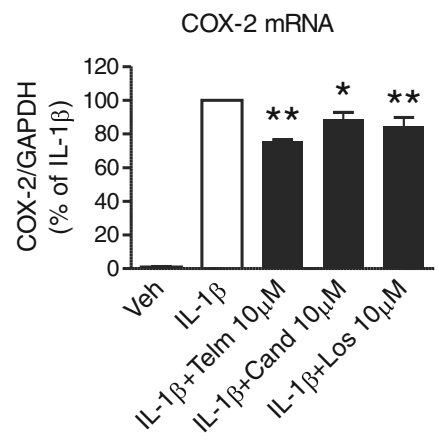

E

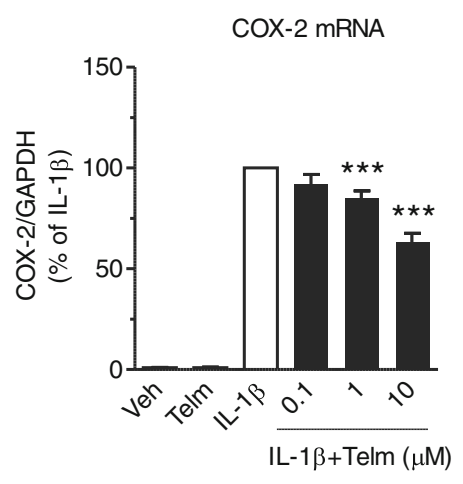

B

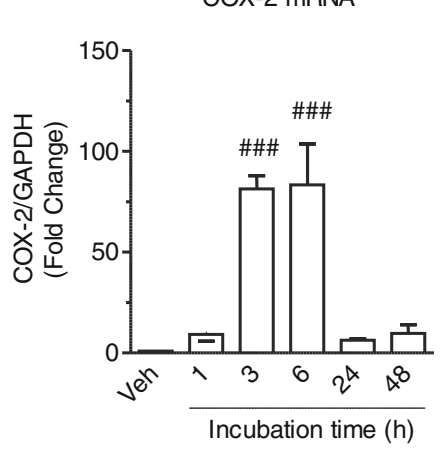

D

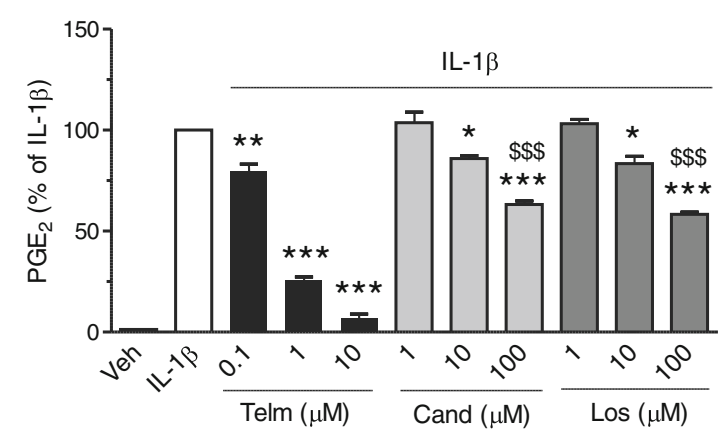

$\mathbf{F}$
COX-2 protein

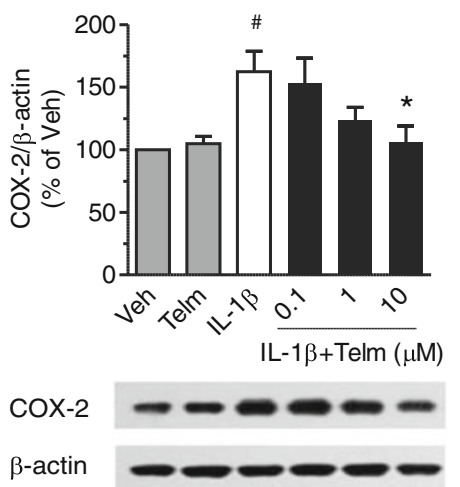

Figure 1 Telmisartan inhibits interleukin-1 beta (IL-1 $\beta$ )-induced cyclooxygenase-2 (COX-2) mRNA and protein expression and prostaglandin $E_{2}\left(P_{G E}\right)$ release in SK-N-SH neuroblasts $(A, B)$ IL-1 $\beta$ dose-dependently and time-dependently induces COX-2 mRNA expression in SK-N-SH neuroblasts. The cells were incubated with (A) the indicated concentrations of IL-1 $\beta$ for 3 hours, or with (B) $10 \mathrm{ng} / \mathrm{ml}$ $\mathrm{IL}-1 \beta$ at indicated time intervals to determine COX-2 mRNA expression. Results are expressed as fold change relative to vehicle-treated group (Veh). (C) Telmisartan, candesartan, and losartan reduced IL-1 $\beta$ induced COX-2 mRNA expression with similar potency. The cells were pretreated

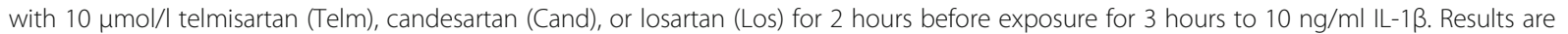
expressed as the percentage of IL-1 $\beta$. (D) Telmisartan was the most effective of $A T_{1}$ receptor blockers at reducing the IL-1 $\beta$-induced PGE $\mathrm{E}_{2}$ release. Cells were pretreated with indicated concentrations of Telm, Cand, or Los for 2 hours before exposure for 24 hours to $10 \mathrm{ng} / \mathrm{ml}$ IL-1 13 to determine cumulative $P G E_{2}$ release. Results are expressed as the percentage of $I L-1 \beta$. (E,F) Telmisartan dose-dependently reduced IL-1 $\beta$-induced COX-2 mRNA and protein expression. The cells were pretreated with indicated concentrations of Telm for 2 hours, then incubated with $10 \mathrm{ng} / \mathrm{ml}$ $\mathrm{IL}-1 \beta$ for (E) 3 hours to determine COX-2 mRNA expression, or (F) 24 hours to determine COX-2 protein expression. The picture is a representative western blot. All results are means \pm SEM from at least three independent experiments. ${ }^{*} P<0.05,{ }^{* *} P<0.01,{ }^{* * *} P<0.001 \mathrm{Vs}$. IL$1 \beta ; \# P<0.05$, \#\#\# $P<0.001$ vs. Veh; $\$ \$ P<0.001$ vs. IL-1 $\beta+10 \mu \mathrm{mol}$ Telm. 
Angiotensin II receptor types in SK-N-SH neuroblasts and the effect of receptor blockade

SK-N-SH neuroblasts expressed $\mathrm{AT}_{1}$ receptor mRNA, and the receptor expression was not affected by IL-1 $\beta$ or telmisartan, either alone or in a combination (Figure 2A).

$\mathrm{AT}_{2}$ receptor mRNA was not detectable in our preparation of SK-N-SH neuroblasts. Incubation in the presence of the $\mathrm{AT}_{2}$ receptor agonist CGP 42112 did not change IL-1 $\beta$ stimulation of COX-2 gene expression (Figure 2B) or $\mathrm{PGE}_{2}$ release (Figure 2C). Similarly, incubation in the presence of the $\mathrm{AT}_{2}$ receptor antagonist PD 123319 did not change IL-1 $\beta$ stimulation of $\mathrm{PGE}_{2}$ release, and did not alter the inhibitory effect of telmisartan (Figure 2C).

\section{Telmisartan prevents interleukin-1 $\beta$-induced NADPH} oxidase activation, reactive oxygen species production and interleukin-1 receptor 1 gene expression

High expression of the NADPH oxidase isoform NOX-4 and substantially lower expression of NOX-5 were found in SK-N-SH neuroblasts (Figure 3A). Expression of NOX-1 and NOX-2 was not detected (Figure 3A). Exposure to IL-1 $\beta$ significantly increased NOX-4 mRNA
A

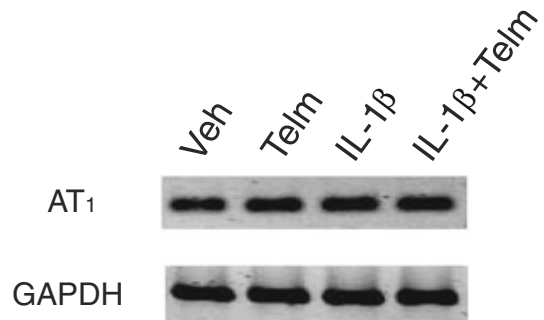

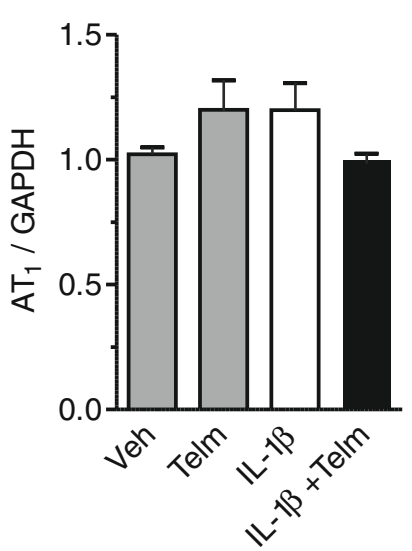

B

COX-2 mRNA

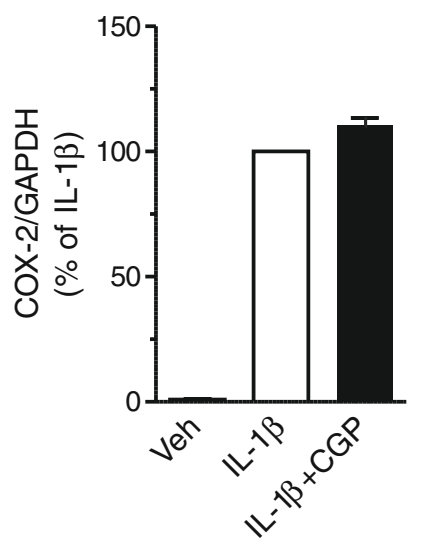

C

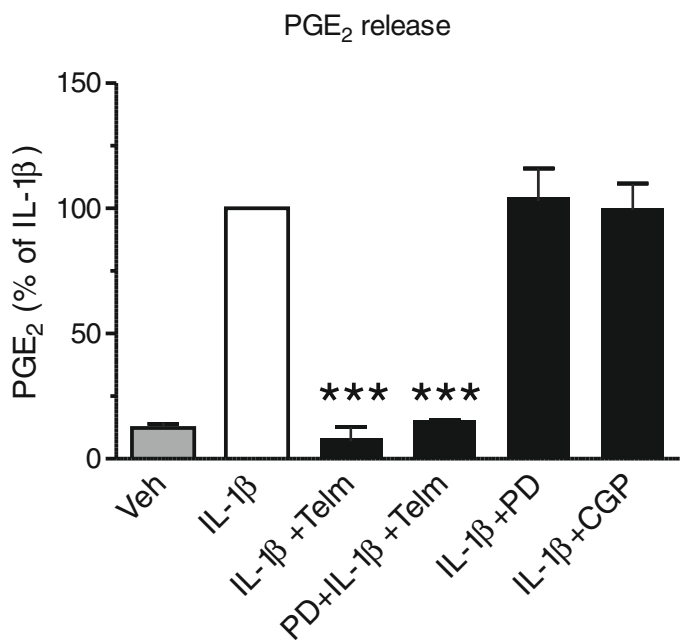

Figure 2 Role of angiotensin II receptor type $1\left(\mathrm{AT}_{1}\right)$ and type $2\left(\mathrm{AT}_{2}\right)$ receptors in interleukin-1 beta (IL-1 $\beta$ )-induced neuronal inflammatory response in SK-N-SH cells. (A) Expression of Angiotensin II AT receptor mRNA in SK-N-SH neuroblasts. The cells were pretreated with $10 \mu \mathrm{mol} / \mathrm{I}$ telmisartan (Telm) for 2 hours before exposure for 3 hours to $10 \mathrm{ng} / \mathrm{ml} \mathrm{IL-1 \beta}$. (Right) AT receptor expression normalized to GAPDH mRNA. The picture shows visualized products of the RT-PCR reaction after separation on agarose gel. (B) Angiotensin II AT 2 receptor agonist CGP 42112 (CGP) does not modify IL-1 $\beta$-induced COX-2 mRNA expression. The cells were pretreated with 1 umol/I CGP 42112 for 2 hours before exposur for 3 hourse to $10 \mathrm{ng} / \mathrm{ml} \mathrm{IL-1 \beta}$. (C) Angiotensin II AT 2 receptor antagonist PD 123319 or $A T_{2}$ receptor agonist CGP 42112 do not affect IL-1 $\beta$-induced $P G E_{2}$ release or the inhibitory effect of telmisartan. The cells were pretreated for 2 hours with $10 \mu \mathrm{mol} / \mathrm{I}$ PD 123319 (PD), $10 \mu \mathrm{mol} / \mathrm{I} \mathrm{CGP}$, or $10 \mu \mathrm{mol} / \mathrm{I}$ Telm alone or in combination with PD, before exposure for 24 hours to $10 \mathrm{ng} / \mathrm{ml} \mathrm{IL}-1 \beta$ to determine cumulative $P G E_{2}$ release. Results are expressed as a percentage of IL-1 $\beta$. All results are means $\pm S E M$ from at least three independent experiments. *** $P<0.001$ vs. IL-1 $\beta$. 


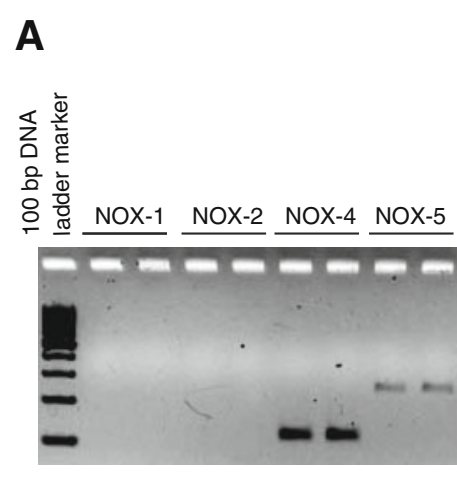

B

D

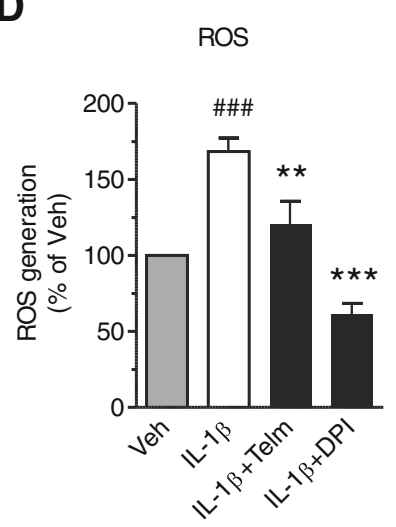

G

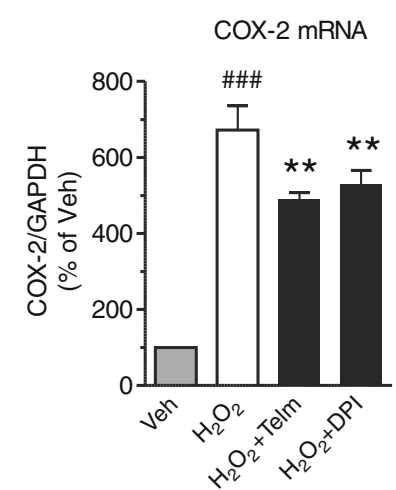

E

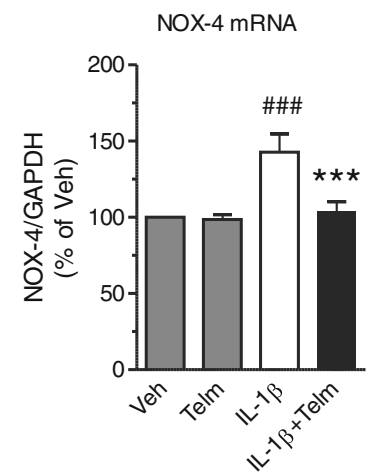

$\mathbf{F}$
C

NADPH oxidase activity

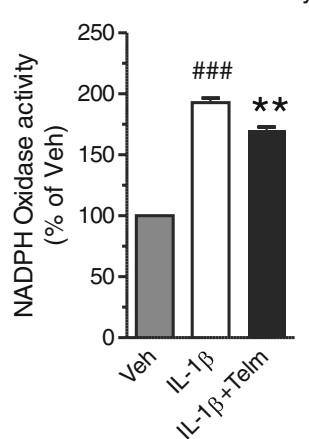

$\mathrm{PGE}_{2}$ release
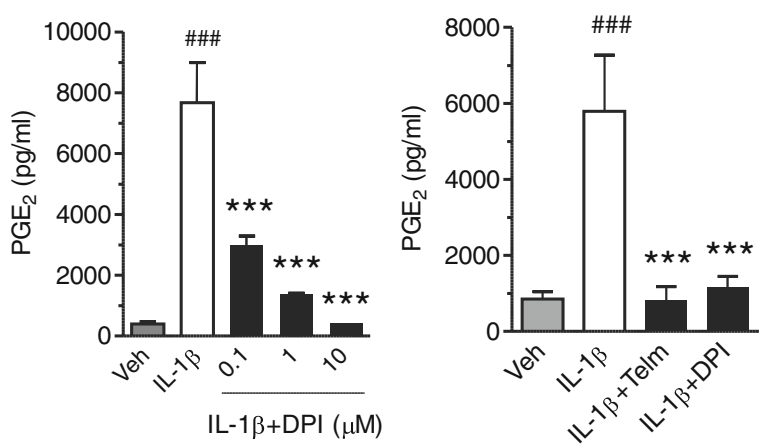

H

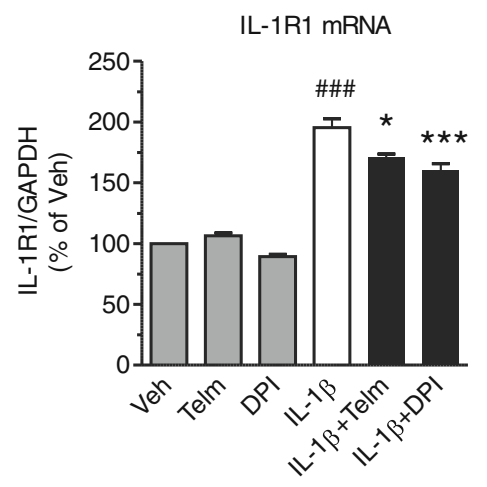

Figure 3 Telmisartan reduces interleukin-1 beta (IL-1 $\beta$ )-induced NADPH oxidase activation, reactive oxygen species formation and IL-1 receptor 1 (IL-1R1) mRNA expression in SK-N-SH neuroblasts. (A) Untreated SK-N-SH cells were analyzed for mRNA expression of different NADPH oxidase isoforms. NADPH oxidase-4 (NOX-4) is the dominant isoform of NADPH oxidase in SK-N-SH neuroblasts. The picture shows visualized products of a RT-PCR reaction after separation in an agarose gel. (B,C) Telmisartan reduced IL-1 $\beta$-induced NOX-4 mRNA expression and NADPH oxidase activity. The cells pretreated with $10 \mu \mathrm{mol} / \mathrm{l}$ telmisartan (Telm) for 2 hours, were incubated with $10 \mathrm{ng} / \mathrm{ml}$ IL-1 $\beta$ for 3 hours to determine (B) NOX-4 mRNA expression and (C) NADPH oxidase activity. (D) Telmisartan reduced IL-1 $\beta$-induced reactive oxygen species (ROS) generation to a lesser extent than does diphenyleneiodonium (DPI). The cells were pretreated with $10 \mu \mathrm{mol} / \mathrm{I}$ Telm or $5 \mu \mathrm{mol} / \mathrm{I}$ DPI for 2 hours before 1 hours exposure to $10 \mathrm{ng} / \mathrm{ml} \mathrm{IL}-1 \beta$ to determine ROS generation. (E,F) DPI dose-dependently inhibited IL-1 $\beta$-induced PGE release with a potency similar to telmisartan. The cells pretreated with indicated concentrations of DPI or Telm for 2 hour were incubated with IL-1 3 for 24 hours to determine cumulative $\mathrm{PGE}_{2}$ release. (G) Both telmisartan and DPI reduce hydrogen peroxide-induced COX-2 mRNA expression. The cells were pretreated with $10 \mu \mathrm{mol} / \mathrm{I}$ Telm or $5 \mu \mathrm{mol} / \mathrm{I}$ DPI for 2 hours before exposure for 3 hours to $100 \mu \mathrm{mol} / \mathrm{l}$ hydrogen peroxide $\left(\mathrm{H}_{2} \mathrm{O}_{2}\right)$ to determine COX-2 mRNA expression. (H) Both telmisartan and DPI reduce IL-1 $\beta$-induced expression of IL-1 $\beta$ receptor IL-1R1 mRNA. The cells were pretreated with $10 \mu \mathrm{mol} / \mathrm{l}$ Telm or $5 \mu \mathrm{mol} / / \mathrm{DPI}$ for 2 hours before exposure for 3 hours to $10 \mathrm{ng} / \mathrm{ml} \mathrm{IL}-1 \beta$ to determine IL-1R1 mRNA expression. Results are presented as a percentage of Veh. All results are means \pm SEM from at least three independent experiments. ${ }^{*} P<0.05$, ${ }^{* *} P<0.01$, *** $P<0.001$ vs. IL-1 $\beta$ or $\mathrm{H}_{2} \mathrm{O}_{2}$; \#\#\# $P<0.001$ vs. Veh. 


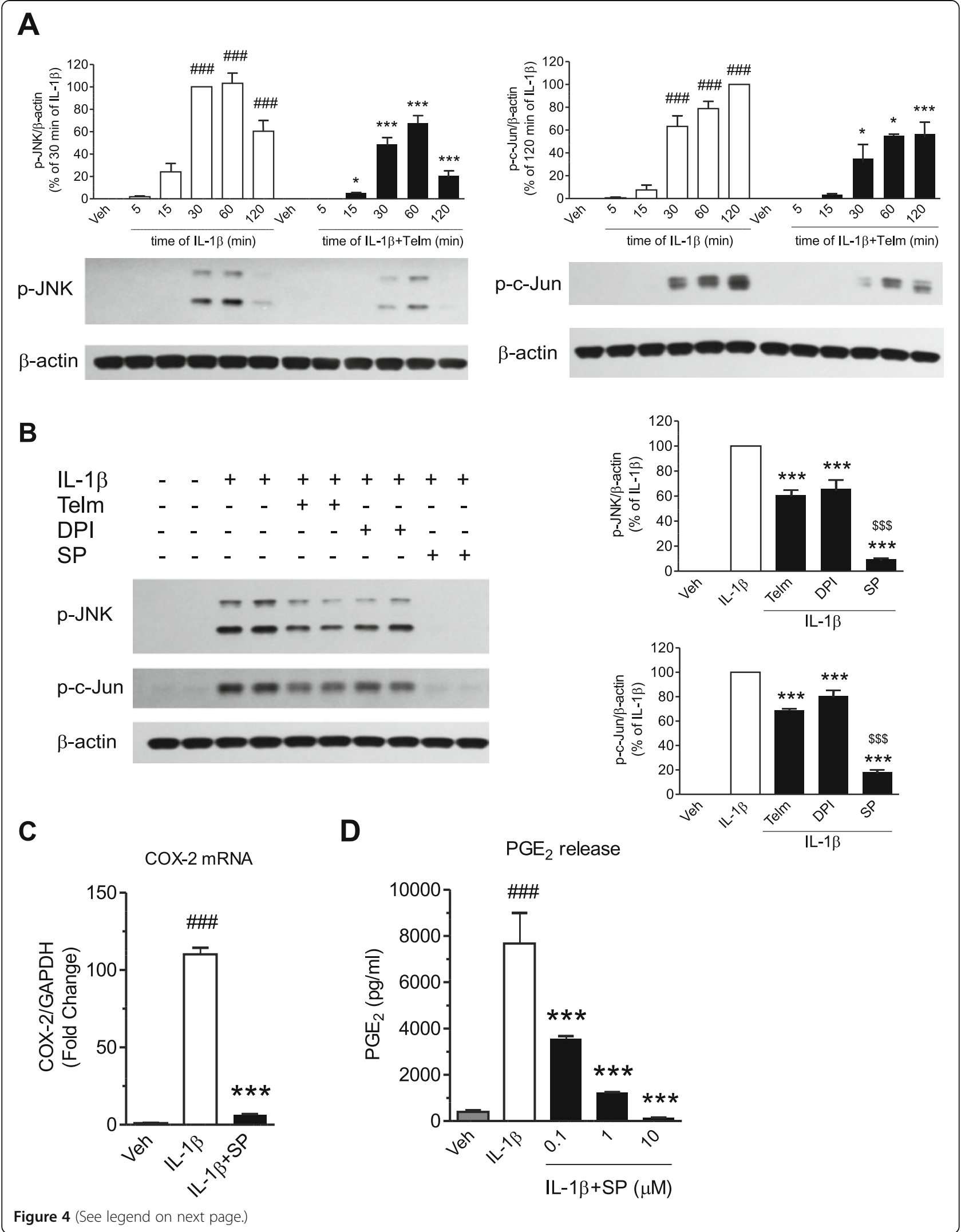


(See figure on previous page.)

Figure 4 Neuroprotective effect of telmisartan is partially mediated through inhibition of the c-Jun N-terminal kinase (JNK)/c-Jun pathway in SK-N-SH neuroblasts. (A) Telmisartan attenuated the time-dependent activation of JNK and c-Jun in response to interleukin-1 beta $(\mathrm{IL}-1 \beta)$. The cells were pretreated for 2 hours with $10 \mu \mathrm{mol} / \mathrm{I}$ telmisartan (Telm) before exposure to $10 \mathrm{ng} / \mathrm{ml} \mathrm{IL}-1 \beta$ for the indicated time intervals. Phosphorylation of JNK and c-Jun was determined by western blotting. Representative blots are shown under the corresponding bar graphs. \#\#\# $P<0.001$ vs. Veh; $P<0.05$, ${ }^{* *} P<0.001$ vs. corresponding IL-1 $\beta$ group. (B) Telmisartan inhibited IL-1 $\beta$-stimulated JNK and $c-J u n$ activation with a potency similar to that of diphenyleneiodonium (DPI) but to a lesser extent than the JNK inhibitor SP600125. The cells were pretreated for 2 hours with $10 \mu \mathrm{mol} / \mathrm{I} \mathrm{Telm}, 5 \mu \mathrm{mol} / \mathrm{I} \mathrm{DPI}$, or $10 \mu \mathrm{mol} / \mathrm{I} \mathrm{SP600125}$ (SP) before exposure for 30 minutes to $10 \mathrm{ng} / \mathrm{ml}$ IL-1 $\beta$. The phosphorylation of JNK and c-Jun was detected as above. Results are shown as a percentage of the IL-1 $\beta$-treated group. (C,D) The JNK inhibitor SP600125 abrogated the IL-1 $\beta$-induced COX-2 mRNA expression and PGE 2 release. The cells were pretreated for (C) 2 hours with $10 \mu m o l / I S P$ before exposure for 3 hours to $10 \mathrm{ng} / \mathrm{ml} \mathrm{IL-1 \beta}$ to determine COX-2 mRNA expression, or with (D) the indicated concentrations of SP600125 before exposure for 24

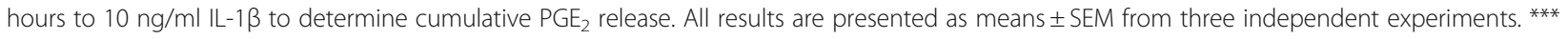
$P<0.001$ vs. IL-1 $\beta$; \#\#\# $P<0.001$ vs. Veh; $\$ \$ P<0.001$ vs. IL-1 $\beta+$ Telm.

expression, and this effect was reduced by telmisartan (Figure 3B). IL-1 $\beta$ significantly increased NADPH oxidase activity, an effect also reduced by telmisartan (Figure 3C). IL-1 $\beta$ enhanced ROS production, and this effect was decreased by both telmisartan and DPI (Figure 3D). DPI dose-dependently inhibited IL-1 $\beta$ induced $\mathrm{PGE}_{2}$ release (Figure $3 \mathrm{E}$ ). The reduction in IL$1 \beta$-stimulated $\mathrm{PGE}_{2}$ release was similar for both telmisartan and DPI (Figure 3F).

Telmisartan reduced the enhanced COX-2 mRNA expression produced by $\mathrm{H}_{2} \mathrm{O}_{2}$ to an extent similar to that resulting from exposure to DPI (Figure 3G).

Exposure to IL-1 $\beta$ enhanced mRNA expression of its receptor, IL-1R1, and this change was reduced to a similar degree by telmisartan and DPI (Figure 3H).

\section{Telmisartan decreases interleukin-1 $\beta$-induced c-Jun $\mathrm{N}$-terminal kinase and c-Jun activation}

IL-1 $\beta$ time-dependently activated JNK in SK-N-SH neuroblasts, reaching maximum stimulation after 30 to 60 minutes of exposure, and this effect was significantly reduced by telmisartan (Figure 4A). Exposure to IL-1 $\beta$ simultaneously and time-dependently enhanced c-Jun phosphorylation, a change significantly decreased by telmisartan (Figure 4A). The effect of telmisartan was of similar magnitude to that of DPI (Figure 4B). Incubation in the presence of the specific JNK inhibitor SP600125 abrogated the IL-1 $\beta$-induced phosphorylation of JNK and c-Jun (Figure 4B), COX-2 mRNA expression (Figure $4 \mathrm{C}$ ), and $\mathrm{PGE}_{2}$ release, in a dose-dependent manner (Figure 4D).

Telmisartan does not affect the interleukin-1 $\beta$-stimulated activation of p38 mitogen-activated protein kinase, extracellular signal-regulated kinase $1 / 2$, or nuclear factor-kB activation

Incubation in the presence of telmisartan did not modify IL-1 $\beta$-induced p38 MAPK phosphorylation (Figure 5A) or the ERK1/2 phosphorylation (Figure $5 \mathrm{~B}$ ). Telmisartan did not change the time-dependent IL-1 $\beta$-induced IкB- $\alpha$ degradation (Figure $6 \mathrm{~A}$ ), the IкB- $\alpha$ mRNA expression
(Figure 6B), or the NF-kB-p65 protein nuclear translocation (Figure 6C). DPI was equally ineffective, and did not change IL-1 $\beta$-induced IKB- $\alpha$ mRNA expression or the NFKB-p65 protein nuclear translocation (Figure $6 \mathrm{~B}$ and $6 \mathrm{C})$.

\section{Peroxisome proliferator-activated receptor- $\gamma$ is not involved in the neuroprotective effect of telmisartan} Incubation of SK-N-SH neuroblasts with the PPARy agonist pioglitazone significantly reduced IL- $1 \beta$-induced COX-2 mRNA expression (Figure 7A), dose-dependently reduced $\mathrm{PGE}_{2}$ release (Figure $7 \mathrm{~B}$ ), and upregulated the mRNA expression of the PPAR $\gamma$ target genes ABCG1 and $C D 36$, without affecting PPAR $\gamma$ mRNA expression (Figure 7C). Conversely, telmisartan did not alter $A B C G 1$ or CD36 mRNA expression (Figure 7C). Incubation of SK-N-SH neuroblasts in the presence of the PPARy antagonists T0070907 or GW9662 alone did not significantly alter IL-1 $\beta$-induced COX-2 mRNA expression (Figure 7D), and neither T0070907 nor GW9662 modified the inhibitory effect of telmisartan on IL-1 $\beta$ induced COX-2 mRNA and protein expression (Figure 7D,E).

\section{Effect of angiotensin II on the telmisartan neuroprotection in SK-N-SH neuroblasts}

Angiotensin II levels were undetectable in the cell-culture medium (results not shown). Exposure of SK-N-SH neuroblasts to $1 \mu \mathrm{mol} / \mathrm{l}$ Ang II for 24 hours did not alter PPAR $\gamma$ gene expression but strongly decreased gene expression of the PPARY target genes ABCG1 and CD36 (Figure 8A). Pretreatment of neuroblasts with Ang II for 24 hours did not change basal COX-2 mRNA expression or basal $\mathrm{PGE}_{2}$ release. Ang II did not affect COX-2 mRNA expression induced by $10 \mathrm{ng} / \mathrm{ml} \mathrm{IL-1} \beta$, but did enhance IL-1 $\beta$-induced $\mathrm{PGE}_{2}$ release (Figure $8 \mathrm{~B}, \mathrm{C}$ ). Pretreatment with Ang II did not change the inhibitory effect of telmisartan on IL-1 $\beta$-stimulated COX-2 gene expression and cumulative $\mathrm{PGE}_{2}$ release (Figure $8 \mathrm{~B}, \mathrm{C}$ ). 
A

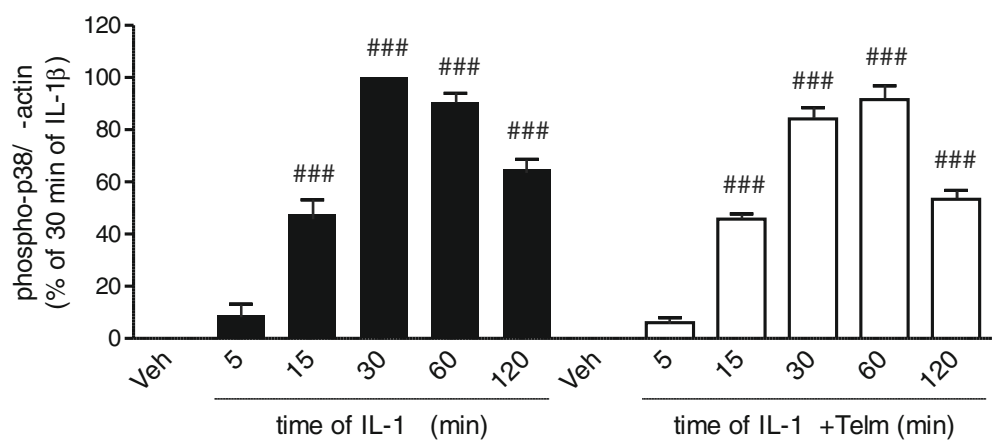

phospho-p38

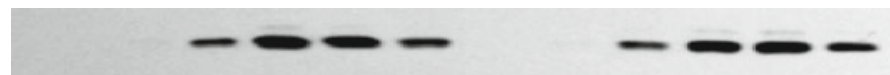

$\beta$-actin

B
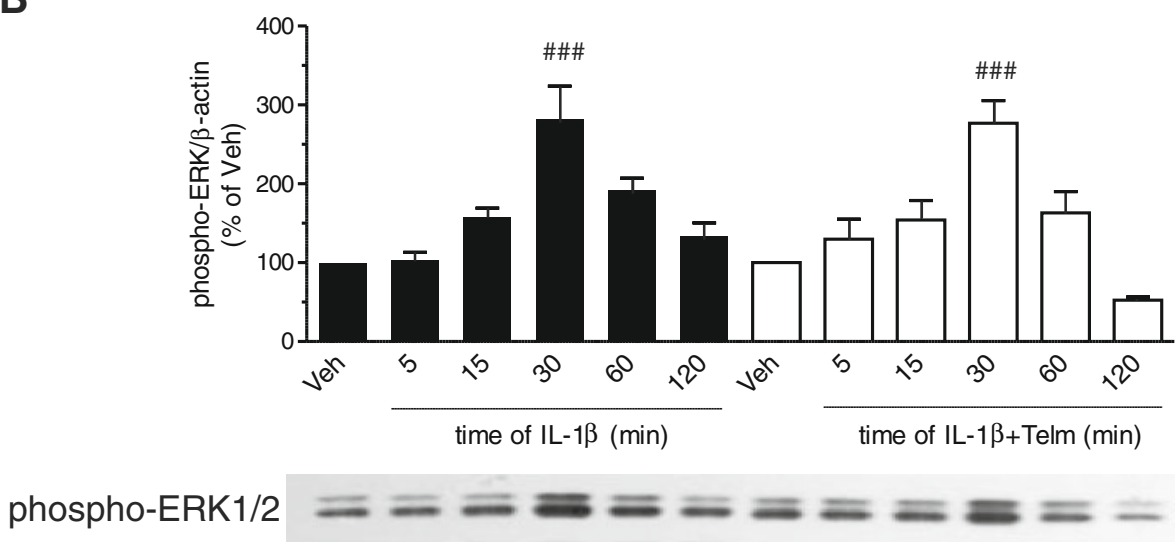

$\beta$-actin

Figure 5 Telmisartan did not alter the interleukin-1 beta (IL-1 $\beta$ )-stimulated activation of p38 mitogen-activated protein kinase (MAPK) or extracellular signal-regulated kinase (ERK) $1 / 2$ in SK-N-SH neuroblasts. (A,B) Cells were pretreated for 2 hours with $10 \mu \mathrm{mol} / \mathrm{l}$ telmisartan (Telm) before exposure to $10 \mathrm{ng} / \mathrm{ml} \mathrm{IL-1 \beta}$ for the indicated time intervals. The phosphorylations of (A) p38 MAPK and (B) ERK1/2 were determined by western blotting and normalized to the levels of $\beta$-actin. All data are presented as means \pm SEM from three independent experiments. Representative blots are shown under the corresponding bar graphs. \#\#\# $P<0.001$ vs. Veh.

Telmisartan reduces interleukin-1 $\beta$ upregulation of reactive oxygen species formation, interleukin-1 receptor type 1 and cyclooxygenase- 2 mRNA expression in primary rat cortical neurons

Exposure of primary rat cortical neurons to IL-1 $\beta$ induced both COX-2 and IL-1R1 mRNA expression and ROS generation, and these effects were significantly reduced by telmisartan (Figure 9A-C).

\section{Discussion}

This study was designed to test the hypothesis that direct neuronal exposure to ARBs is neuroprotective. IL-1 $\beta$ was selected based on its well-characterized participation in neuronal injury associated with inflammatory and neurodegenerative diseases of the brain [6-10]. The principal finding of our study is that ARBs, in particular telmisartan, directly and significantly ameliorate the IL-1 $\beta$ induced neuronal inflammatory response.

Ang II stimulates two receptor types, the $\mathrm{AT}_{1}$ and $\mathrm{AT}_{2}$ receptors [43]. Excessive $\mathrm{AT}_{1}$ receptor stimulation is associated with brain inflammation, whereas stimulation of $\mathrm{AT}_{2}$ receptors has been proposed to exert balancing neuroprotective effects, particularly when $\mathrm{AT}_{1}$ receptors are blocked by ARB administration [43-45]. SK-N-SH human neuroblasts expressed $\mathrm{AT}_{1}$ receptor mRNA, whereas $\mathrm{AT}_{2}$ receptor mRNA was undetectable in these 
A

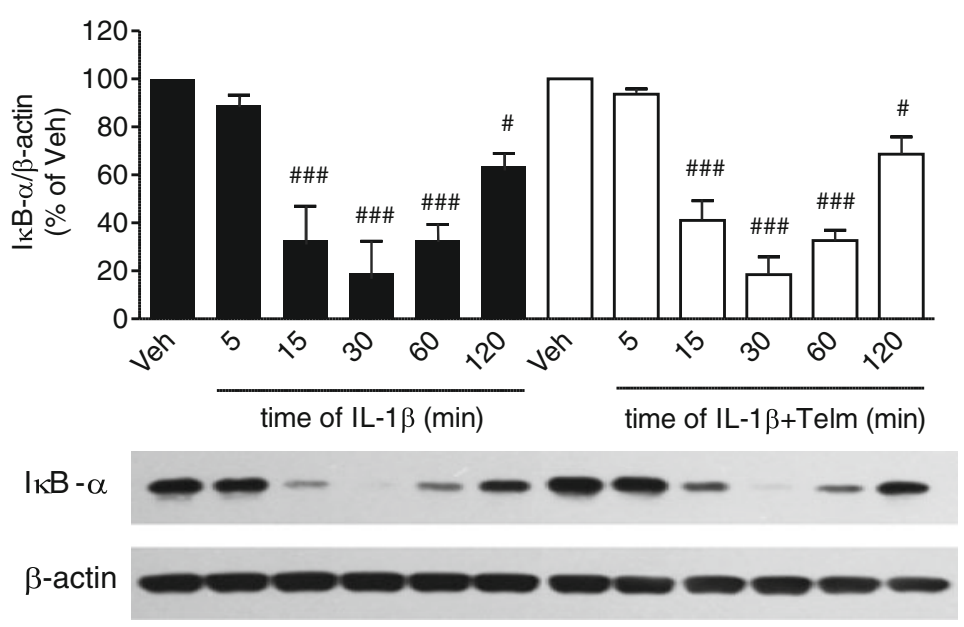

B

C nuclear NFkB-p65
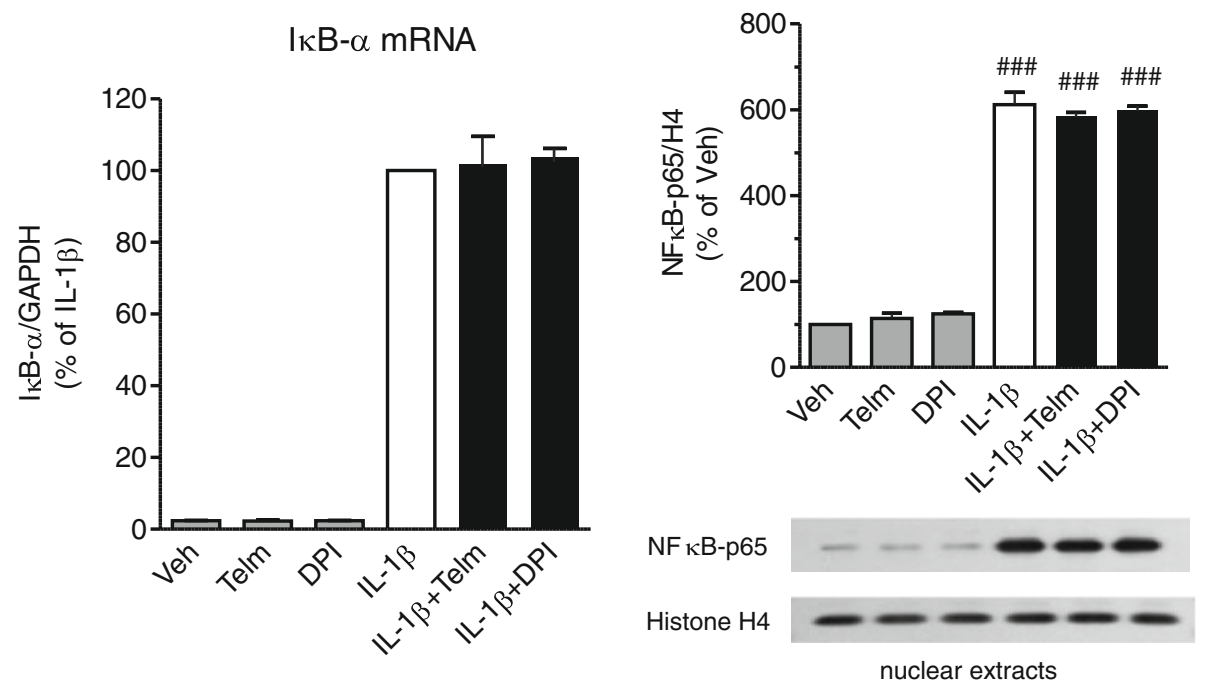

Figure 6 The nuclear factor-kappa B (NF-KB) pathway is not involved in the neuroprotective effect of telmisartan in SK-N-SH neuroblasts. (A) Telmisartan does not prevent time-dependent IKB-a protein degradation in cells in response to interleukin-1 beta (IL-1 $\beta$ ). Cells were pretreated for 2 hours with $10 \mu \mathrm{mol} / \mathrm{l}$ telmisartan (Telm) before exposure to $10 \mathrm{ng} / \mathrm{ml} \mathrm{IL}-1 \beta$ for the indicated time intervals. IkB-a protein levels were determined in whole-cell extracts, and normalized to $\beta$-actin. (B) Neither telmisartan nor diphenyleneiodonium (DPI) modified IL-1 $\beta$ induced expression of IKB-a mRNA. The cells were pretreated for 2 hours with $10 \mu \mathrm{mol} / \mathrm{l}$ Telm or $5 \mu \mathrm{mol} / \mathrm{l}$ DPI before exposure for 3 hours to $10 \mathrm{ng} / \mathrm{ml} \mathrm{IL-1 \beta}$ to determine IKB-a mRNA expression. (C) Neither telmisartan nor DPI affected IL-1 $\beta$-induced nuclear translocation of the NF-KB p65 subunit. The cells were pretreated for 2 hours with $10 \mu \mathrm{mol} / \mathrm{I}$ Telm or $5 \mu \mathrm{mol} / \mathrm{I}$ DPI before exposure for $30 \mathrm{minutes}$ to $10 \mathrm{ng} / \mathrm{ml}$ IL-1 $\beta$. The NF-KB p65 subunit protein was determined in nuclear extracts and normalized to the level of the nuclear protein histone H4. Representative western blots are shown below the corresponding bar graphs. Results are presented as means \pm SEM from three independent experiments. $\# P<0.05$, \#\#\# $P<0.001$ vs. Veh.

cells. Furthermore, exposure of SK-N-SH neuroblasts to $\mathrm{PD} 123319$ (an $\mathrm{AT}_{2}$ receptor antagonist) or CGP 42112 (an $\mathrm{AT}_{2}$ receptor agonist) did not change the effects of IL-1 $\beta$, and PD 123319 did not modify the neuroprotective effect of telmisartan. These results indicate that the neuroprotective effect of telmisartan and other ARBs in SK-N-SH neuroblasts is dependent on $\mathrm{AT}_{1}$ receptor blockade without involvement of $\mathrm{AT}_{2}$ receptors.
The neurotoxic effects of IL-1 $\beta$, confirmed in this study, have been well characterized. They depend on stimulation of the IL-1R1 receptor, and characteristically involve NADPH oxidase activation and ROS formation, COX-2 induction, and $\mathrm{PGE}_{2}$ production and release, leading to neuronal toxicity and apoptosis $[5,37,38,46$ 49]. Our results support the hypothesis that IL-1 $\beta$, when produced in excess by activated microglia, may directly 


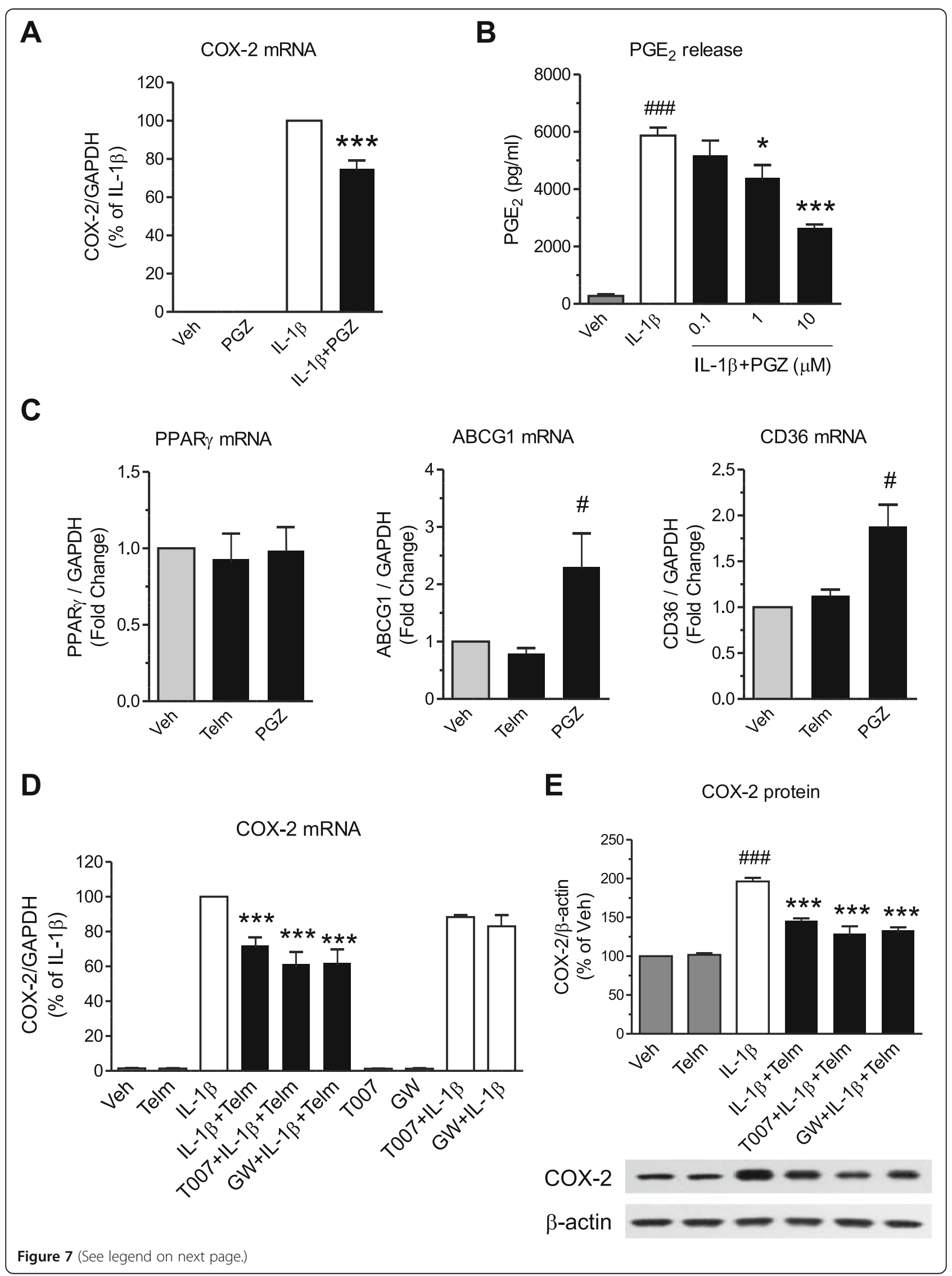


(See figure on previous page.)

Figure 7 Peroxisome proliferator-activated receptor gamma (PPAR $\gamma$ ) activation is not involved in the neuroprotective effect of telmisartan in SK-N-SH neuroblasts. (A,B) The PPARY agonist pioglitazone inhibited interleukin-1 beta (IL-1 $\beta$ )-induced cyclooxygenase-2 (COX2) gene expression and prostaglandin $E_{2}\left(P G E_{2}\right)$ release. The cells were pretreated for $(\mathbf{A}) 2$ hours with $10 \mu \mathrm{mol} / \mathrm{l}$ pioglitazone (PGZ) before exposure for 3 hours to $10 \mathrm{ng} / \mathrm{ml}$ IL-1 $\beta$ to determine COX-2 mRNA expression or (B) with indicated concentrations of PGZ before exposure for 24 hours to $10 \mathrm{ng} / \mathrm{ml} \mathrm{IL}-1 \beta$ to determine cumulative PGE 2 release. (C) Pioglitazone, but not telmisartan, induced gene expression of the PPARY target genes $A B C G 1$ and CD36. The cells were incubated for 3 hours with $10 \mu \mathrm{mol} / \mathrm{I}$ PGZ or $10 \mu \mathrm{mol} / \mathrm{I}$ Telm to determine gene expression of PPARY and its target genes ABCG1 and CD36. Results are shown as fold change relative to the vehicle-treated group (Veh). (D,E) PPARY antagonists did not change the inhibitory effect of telmisartan on IL-1 $\beta$-induced COX-2 expression. The cells were pretreated for 1 hour with $1 \mu \mathrm{mol} / \mathrm{I}$ T0070907 (T007) or $20 \mu \mathrm{mol} / \mathrm{I}$ GW9662 (GW), followed by $10 \mu \mathrm{mol} / \mathrm{I}$ Telm for 2 hours before exposure for (D) 3 hours to $10 \mathrm{ng} / \mathrm{ml}$ IL-1 $\beta$ to determine COX-2 mRNA, or (E) 24 hours of IL-1 $\beta$ to determine COX-2 protein expression. The picture below is a representative western blot. All results are means \pm SEM from at least three independent experiments. ${ }^{*} P<0.05,{ }^{* * *} P<0.001 \mathrm{vs}$. IL-1 $\beta$; \# $P<0.05$, \#\#\# $P<0.001$ vs. Veh.

generate further inflammatory cascades in neurons, contributing to their increased vulnerability to injury.

Telmisartan, at concentrations similar to those found in clinical studies [50], significantly reduced the neuronal inflammatory response induced by IL-1 $\beta$. Most of the downstream pathways activated by IL- $1 \beta$ in the present study, including IL-1R1 receptor upregulation, are associated with NADPH oxidase activation [51,52]. This

A
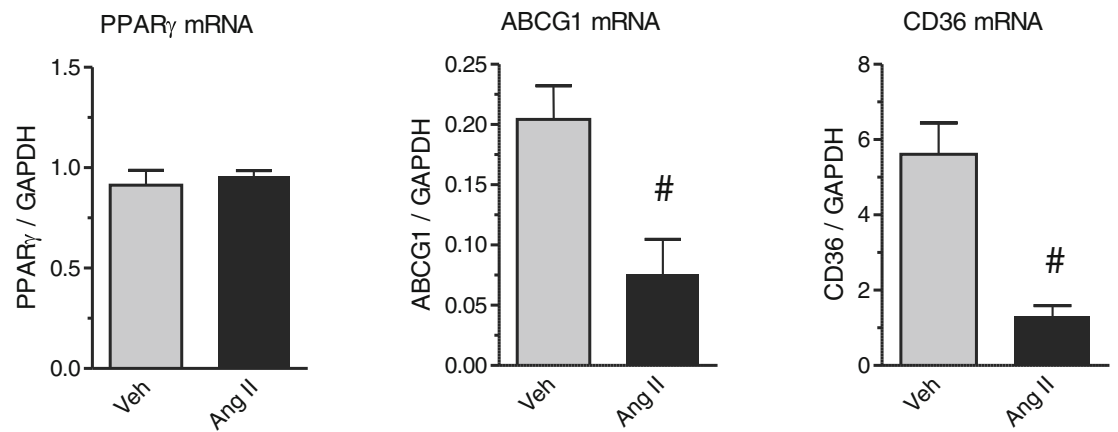

B

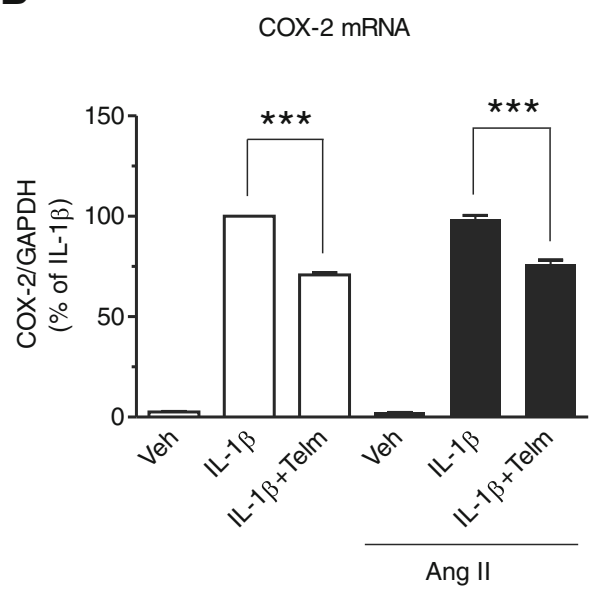

C

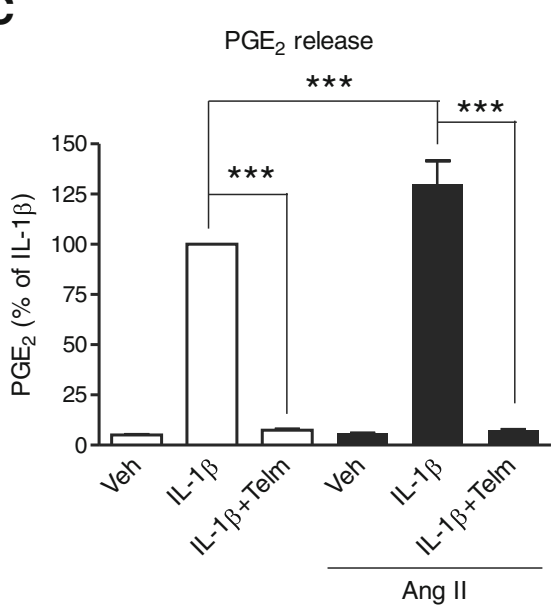

Figure 8 Effect of Angiotensin II (Ang II) on SK-N-SH neuroblasts. (A) Ang II did not affect peroxisome proliferator-activated receptor gamma (PPARY) gene expression, but strongly inhibited the expression of the PPARy target genes ABCG1 and CD36. The cells were treated with $1 \mu \mathrm{mol} / \mathrm{I}$ Ang II for 24 hours to determine PPARY, ABCG1 and CD36 mRNA expression. \# $P<0.05$ vs. Veh. (B) Ang II affected neither interleukin-1 beta (IL$1 \beta$ )-induced cyclooxygenase-2 (COX-2) mRNA expression nor the inhibitory effects of telmisartan. Cells cultured for 24 hours in the presence of $1 \mu \mathrm{mol} / \mathrm{l}$ Ang II were pretreated for 2 hours with $10 \mu \mathrm{mol} / \mathrm{I}$ telmisartan (Telm) before exposure for 3 hours to $10 \mathrm{ng} / \mathrm{ml} \mathrm{IL}-1 \beta$ to determine COX-2 mRNA expression. Results are presented as a percentage of the IL-1 $\beta$-treated group. (C) Ang II augmented IL-1 $\beta$-induced PGE 2 release but did not modify the inhibitory effect of telmisartan. The cells, cultured for 24 hours in the presence of $1 \mu \mathrm{mol} / \mathrm{I}$ Ang $\mathrm{Il}$, were pretreated for 2 hours with $10 \mu \mathrm{mol} / \mathrm{l}$ Telm before exposure for 24 hours to $10 \mathrm{ng} / \mathrm{ml} \mathrm{IL-1 \beta}$ to determine cumulative PGE release. Results are presented as a percentage of $\mathrm{IL}-1 \beta$. All results are means \pm SEM from at least three independent experiments. ${ }^{* * *} P<0.001$. 
A

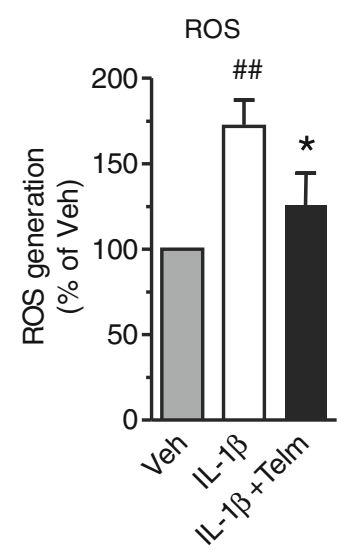

B

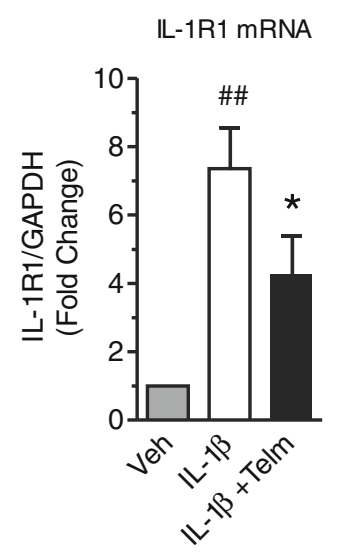

C

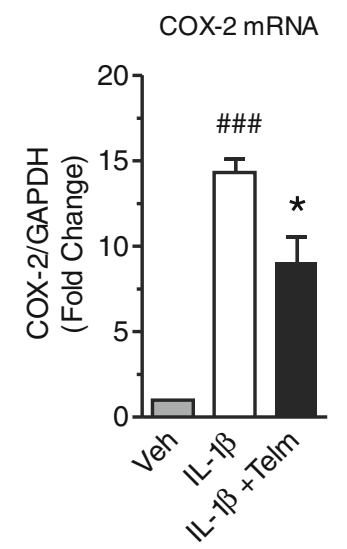

Figure 9 Telmisartan inhibits interleukin-1 beta (IL-1 $\beta$ )-induced reactive oxygen species (ROS) generation, interleukin-1 receptor type 1 (IL-1R1) and cyclooxygenase-2 (COX-2) gene expression in primary rat cortical neurons. Cells were pretreated for 2 hours with $10 \mu \mathrm{mol} / \mathrm{l}$ telmisartan (Telm) before exposure for 2 hours to $1 \mathrm{ng} / \mathrm{ml} \mathrm{IL-1 \beta}$ to determine (A) ROS generation, and (B, C) IL-1R1 and COX-2 mRNA expression. Results are means \pm SEM from at least three independent experiments. ${ }^{*} P<0.05$ vs. IL-1 $\beta$; \#\# $P<0.01, \# \# \#<0.001$ vs. Veh.

indicates that inhibition of NADPH oxidase activity by telmisartan is a major neuroprotective mechanism. Telmisartan decreased not only IL- $1 \beta$-induced ROS formation but also $\mathrm{H}_{2} \mathrm{O}_{2}$-induced COX-2 expression, suggesting that reduction of the intracellular ROS and ROS-related downstream pathway [10] may be important for the neuroprotective effects of telmisartan. The wide-ranging anti-oxidant effects described here were similar to those reported previously in non-neuronal cell lines [53] and were of a potency similar to that of the NADPH oxidase and NOS inhibitor DPI [54,55]. These results are in agreement with observations showing that ARBs decrease NADPH oxidase activation associated with oxidative stress and neuronal apoptosis [36,56,57]. The neuroprotective effects of telmisartan were replicated in rat primary cortical neurons, indicating that they were not limited to responses only in the neuroblast preparations.

The discovery that telmisartan significantly prevents the IL-1 $\beta$-induced upregulation of its receptor IL-1R1 in both SK-N-SH neuroblasts and rat primary cortical neurons is of major interest. Most of the IL- $1 \beta$ effects are mediated by IL-1R1 receptor stimulation. Administration of IL-1R1 receptor inhibitors seems to lead to amelioration of brain inflammation, and protection from stroke and traumatic brain injury, thus the development of novel IL-1R1 receptor inhibitors is the subject of active research $[12,13]$. For these reasons, our finding that telmisartan significantly prevents IL-1 $\beta$ induction of its receptor indicates an additional anti-inflammatory mechanism that might be of clinical value.

In agreement with previous observations [58], we found that IL-1 $\beta$ significantly stimulates a number of kinases, including p38 MAPK, ERK1/2, and JNK/c-Jun, and produces a notable activation of NF- $\mathrm{kB}$ in human SK-N-SH neuroblasts. Incubation in the presence of telmisartan significantly reduced IL- $1 \beta$-induced JNK/c-Jun activation, but had no effect on activation of p38 MAPK, ERK1/2, and NF-KB. Stimulation of inflammatory cascades is to a considerable extent the result of activation of the transcription factor NF- $\mathrm{kB}$ [10]. Our observations are therefore no unexpected and concur with those of previous studies showing that anti-inflammatory mechanisms are cell-specific, depending on the inflammatory component and on the anti-inflammatory agent studied. In monocytes, macrophages, and microglia, NF$\kappa B$ activation seems to be a major factor leading to inflammation and $\mathrm{COX}-2 / \mathrm{PGE}_{2}$ production $[10,41,49]$. However, in brain endothelial cell lines, several important components of the IL- $1 \beta$-induced inflammatory response are independent of MAPK activity [9]. Moreover, glucocorticoids reduce IL-1 $\beta$-induced inflammation in cells of neural origin by mechanisms independently of NF-kB [59]. These results and our present findings indicate that factors independent of NF- $\mathrm{kB}$ play a major role in the anti-inflammatory effect of ARBs in neurons.

All ARBs inhibit the Ang II-induced effects associated with stimulation of physiological $\mathrm{AT}_{1}$ receptors, but some ARBs, particularly telmisartan, are also partial PPAR $\gamma$ agonists $[39,40]$. Surprisingly in SK-N-SH neuroblasts, telmisartan failed to activate PPAR $\gamma$. Furthermore, addition of PPAR $\gamma$ antagonists did not modify the neuroprotective effects of telmisartan, indicating that in these cells, $\mathrm{AT}_{1}$ receptor inhibition rather than PPARY activation may be the primary mechanism for the direct anti-inflammatory effects of ARBs. These observations 
apparently contrast with the initial demonstration of PPAR $\gamma$ activation by telmisartan in cell culture [39,40], the PPAR $\gamma$-associated anti-inflammatory effects of telmisartan in cultured human monocytes and THP-1 cells [41], and the PPAR $\gamma$-activating neuroprotective effects of telmisartan shown in vivo [23,31,32].

It has been reported that although conventional PPAR $\gamma$ agonists can suppress expression of proinflammatory factors in primary microglia, they do not suppress expression of pro-inflammatory molecules in a microglial cell line expressing little or no PPAR $\gamma$ $[60,61]$, and are not neuroprotective when applied to neurons [62]. In the SK-N-SH neuroblast preparations used in the present study, the PPAR $\gamma$ gene was expressed at relatively low levels compared with $\mathrm{AT}_{1}$ receptors (data not shown). However, in spite of the low PPAR $\gamma$ gene expression, a conventional PPAR $\gamma$ full agonist, pioglitazone [63], significantly activated PPAR $\gamma$ in SK-N-SH neuroblasts. Conversely, under identical experimental conditions, telmisartan was ineffective, indicating that PPARY activation is neuroprotective but is not mediating the effects of telmisartan in SK-N-SH neuroblasts.

Indeed, the PPAR $\gamma$ agonist properties of individual ARBs seem to depend on the cell type studied and on the conditions of the experiments. Reports from cellculture studies indicated that the PPAR $\gamma$ agonist effects of candesartan and losartan are not high $[39,40]$; however, losartan has been found to increase PPARy activation in certain cell types [64,65], and long-term candesartan treatment upregulates PPAR $\gamma$ gene expression in vivo in adipose tissue [66]. Further studies are necessary to clarify the relative contribution of $\mathrm{AT}_{1}$ receptor blockade and the PPARY agonist activity of ARBs in specific cell populations. Whether the PPARy agonist effect of ARBs may be dependent on the degree of PPARy gene expression remains an open question.

It is known that Ang II strongly inhibits PPAR $\gamma$ activation, an effect dependent on $\mathrm{AT}_{1}$ receptor stimulation, and the absence of Ang II may substantially stimulate PPAR $\gamma$ activity $[45,67,68]$. In accordance with this, addition of a high Ang II concentration decreased expression of PPAR $\gamma$ target genes in our study. However, in our studies, Ang II levels in the cell-culture media were below the $1.5 \mathrm{pg} / \mathrm{ml}$ (corresponding to 1.5 $\mathrm{pmol} / \mathrm{l}$ ) limit of detection. A concentration of $1 \mu \mathrm{mol} / \mathrm{l}$ of Ang II was required to produce a small increase in the IL-1 $\beta$-induced $\mathrm{PGE}_{2}$ release, whereas it did not change COX-2 induction, had no effect on NADPH oxidase expression or activity (data not shown), and did not influence the protective effects of telmisartan. For these reasons, it is very likely that in SK-N-SH neuroblasts, the neuroprotective effects of telmisartan are independent of Ang II-mediated stimulation of $\mathrm{AT}_{1}$ receptors. Ligand-independent $\mathrm{AT}_{1}$ receptor activation has been reported previously in cardiomyocytes as a consequence of mechanical stress [69].

Based on the present results, we propose that, in SK-N$\mathrm{SH}$ neuroblasts, the $\mathrm{AT}_{1}$ receptor may be constitutively active, and the neuroprotective effects of telmisartan and other ARBs may be the result of a decrease of such constitutive $\mathrm{AT}_{1}$ receptor activity. Recently, the constitutive activity of $\mathrm{AT}_{1}$ receptor has been reported under basal conditions in vivo even in the absence of Ang II [70]. However, there are no reports of ligand-independent activation or constitutive $\mathrm{AT}_{1}$ receptor activity in neurons, and the hypothesis of constitutively active neuronal $\mathrm{AT}_{1}$ receptors requires further confirmation.

Although it must be considered that neuronal cultures may not be representative of in vivo conditions, the SK$\mathrm{N}-\mathrm{SH}$ neuroblasts cultures are a good in vitro model to study the mechanisms of action responsible for direct ARB neuroprotection.

The present observations and those of the literature suggest that ARBs may exert neuroprotective effects by several associated mechanisms: decreasing inflammationinduced circulating IL-1 $\beta$ levels affecting the brain and activating microglia in brain parenchyma, by direct antiinflammatory effects in microglia as shown in isolated microglia in culture [15], and by direct effects in neurons, ameliorating the neuronal inflammatory responses produced by excess IL-1 $\beta$, as reported here and illustrated in Figure 10.

Our results have important clinical implications. IL-1 $\beta$ is a strong stimulant of oxidative stress, COX-2 production, and $\mathrm{PGE}_{2}$ release, and it has been clearly associated with both acute and chronic inflammatory conditions of the brain. Neuronal induction of COX-2, leading to increased release of its product $\mathrm{PGE}_{2}$, is strongly stimulated by IL-1 $\beta$, and has been linked to neuroinflammatory aspects of neurodegenerative diseases such as $\mathrm{AD}$ and HIV-associated dementia [38,71-73]. Furthermore, it was reported that maximal COX-2 expression predates maximal activation of astrocytes and microglia in the early stages of $\mathrm{AD}$ [74]. For this reason, the direct neuroprotective effects of ARBs reported here may be of major clinical significance.

Our present observations may explain the recent findings that ARB administration for the treatment of hypertension significantly protects cognition, and ameliorates the incidence and progression of $\mathrm{AD}$, and that the neuroprotective effects of ARBs seem to be superior to those of similarly potent anti-hypertensive medications without direct effect on $\mathrm{AT}_{1}$ receptors [75,76]. These clinical observations are supported by pre-clinical studies, showing that ARBs reduce NADPH oxidase activation and neuronal apoptosis and protect cognition in animal models of AD and PD [36]. 


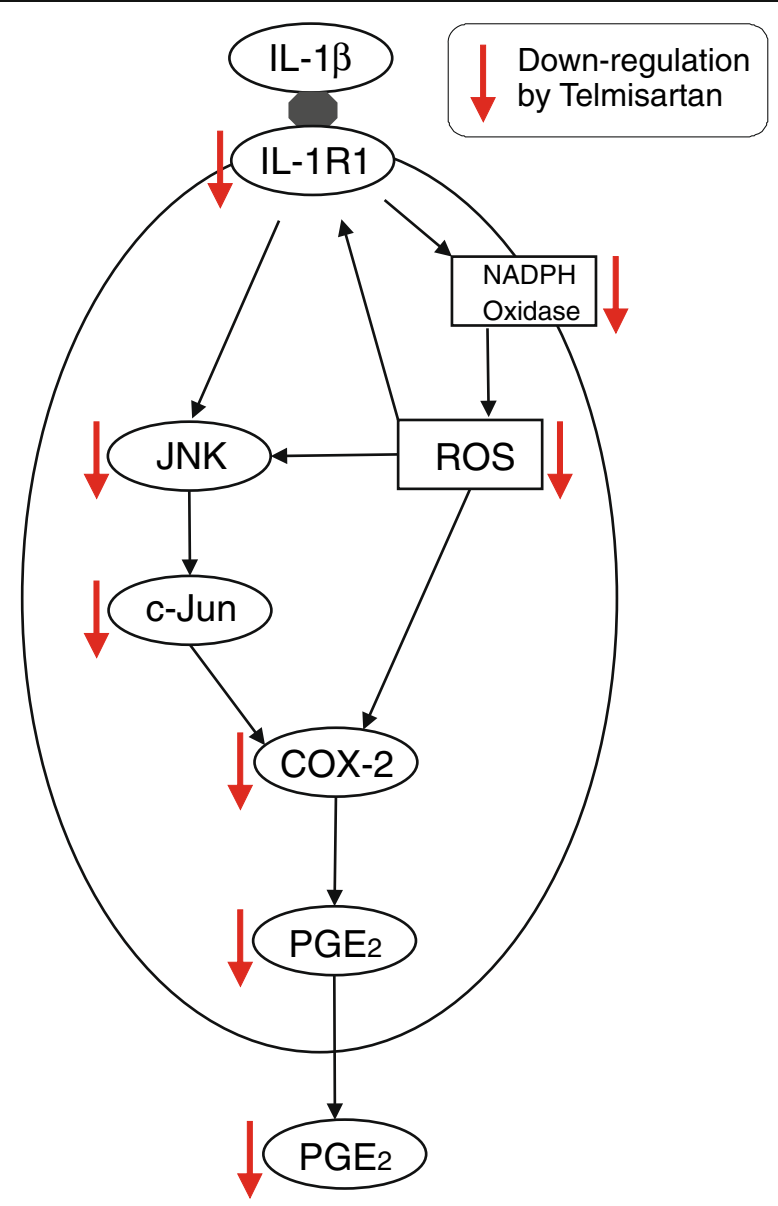

Figure 10 Proposed pathways involved in the neuroprotective effects of telmisartan. The pro-inflammatory effects of interleukin-1 beta (IL$1 \beta)$ in neurons are the consequence of binding to its IL-1R1 receptor, which in turn increases NADPH oxidase activation, reactive oxygen species (ROS) formation, c-Jun N-terminal kinase (JNK) and c-Jun activation, and IL-1 receptor 1 (IL-1R1) gene expression. This results in enhanced expression of COX-2 and prostaglandin $E_{2}\left(P_{G} E_{2}\right)$. Telmisartan abrogates these pro-inflammatory effects of IL-1 $\beta$ by mechanisms involving inhibition of NADPH oxidase activation and the JNK/C-Jun pathway.

\section{Conclusions}

Our observations highlight the pleiotropic neuroprotective effects of ARBs. As reported previously, these compounds reduce the inflammation-induced production of circulating inflammatory cytokines affecting the brain and inflammation-induced microglial activation, significantly diminishing inflammatory cascades. As we show here, ARBs directly decrease the pro-inflammatory effects of IL-1 $\beta$ in neurons, including reduction of IL-1 $\beta$ receptor upregulation, NADPH oxidase activation, ROS production, JNK and c-Jun activation, and proinflammatory $\mathrm{COX}-2 / \mathrm{PGE}_{2}$. We propose that ARBs may not only reduce production of excessive proinflammatory factors, but also decrease neuronal vulnerability to injury. These properties are of significant clinical value, and help to explain the increasing evidence that treatment with ARBs ameliorates the incidence and progression of acute and chronic neurodegenerative conditions such as AD and stroke, in which neuroinflammation plays an important role.

\section{Abbreviations}

AD: Alzheimer's disease; Ang II: Angiotensin II; ARB: Angiotensin II receptor blocker; AT1: Angiotensin II receptor, type 1; COX-2: Cyclooxygenase-2; DMEM: Dulbecco's modified Eagle's medium; DMSO: Dimethyl sulfoxide; DPI: Diphenyleneiodonium; EIA: Enzyme immunoassay; ERK1/2: Extracellular signal-regulated kinases 1/2; FBS: Fetal bovine serum; GAPDH: Glyceraldehyde 3-phosphate dehydrogenase: H2DCFDA: Dichlorodihydrofluorescein diacetate; IkB-a: Inhibitor of kappa B alpha; IL-1ß: Interleukin-1 beta; IL-1R1: Interleukin 1 receptor 1; IL6: Interleukin-6; JNK: c-Jun N-terminal kinase; MAPK: Mitogen-activated protein kinase; MEM: Minimum essential medium; NADPH: Nicotinamide adenine dinucleotide phosphate; NF-kB: Nuclear factor-kappa B; NOX: NADPH oxidase; PD: Parkinson's disease; PGE2: Prostaglandin E2; PPARY: Peroxisome proliferator-activated receptor gamma; RAS: Reninangiotensin system; ROS: Reactive oxygen species; RT: Reverse transcriptase.

\section{Competing interests}

The authors declare that they have no competing interests. 


\section{Acknowledgements}

This study was supported by the Division of Intramural Research Programs, National Institute of Mental Health, National Institutes of Health, Department of Health and Human Services, USA.

\section{Authors' contributions}

TP, JW, JB, and ES performed the experiments. TP, JMS conceived of and designed the experimental plan, and wrote the manuscript. All authors have read and approved the final version of the manuscript.

Received: 14 December 2011 Accepted: 29 May 2012 Published: 29 May 2012

\section{References}

1. Vitkovic L, Bockaert J, Jacque C: "Inflammatory" cytokines: neuromodulators in normal brain? J Neurochem 2000, 74:457-471.

2. Pinteaux E, Trotter P, Simi A: Cell-specific and concentration-dependent actions of interleukin-1 in acute brain inflammation. Cytokine 2009, 45:1-7.

3. Dinarello CA: The IL-1 family and inflammatory diseases. Clin Exp Rheumatol 2002, 20:S1-S13.

4. Rothwell NJ, Luheshi GN: Interleukin 1 in the brain: biology, pathology and therapeuric target. Trends Neurosci 2000, 23:618-625.

5. Rothwell N: Interleukin-1 and neuronal injury: mechanisms, modification, and therapeutic potential. Brain Behav Immun 2003, 17:152-157.

6. Pascoe MC, Crewther SG, Carey LM, Crewther DP: Inflammation and depression: why poststroke depression may be the norm and not the exception. Int J Stroke 2011, 6:128-135.

7. Wang $P$, Rothwell NJ, Pinteaux E, Brough D: Neuronal injury induces the release of pro-interleukin-1beta from activated microglia in vitro. Brain Res 2008, 1236:1-7.

8. Lull ME, Block ML: Microglial activation and chronic neurodegeneration. Neurotherapeutics 2010, 7:354-365.

9. Thornton P, McColl BW, Cooper L, Rothwell NJ, Allan SM: Interleukin-1 drives cerebrovascular inflammation via MAP kinase-independent pathways. Curr Neurovasc Res 2010, 7:330-340

10. Brown GC, Neher JJ: Inflammatory neurodegeneration and mechanisms of microglial killing of neurons. Mol Neurobiol 2010, 41:242-247.

11. Nimmo AJ, Vink R: Recent patents in CNS drug discovery: the management of inflammation in the central nervous system. Recent Pat CNS Drug Discov 2009, 4:86-95.

12. Skinner RA, Gibson RM, Rothwell NJ, Pinteaux E, Penny Jl: Transport of interleukin-1 across cerebromicrovascular endothelial cells. $\mathrm{Br} J$ Pharmacol 2009, 156:1115-1123.

13. Denes A, Pinteaux E, Rothwell NJ, Allan SM: Interleukin-1 and stroke: biomarker, harbinger of damage, and therapeutic target. Cerebrovasc Dis 2011, 32:517-527.

14. Zhang ZH, Yu Y, Wei SG, Felder RB: Centrally administered lipopolysaccharide elicits sympathetic excitation via $\mathrm{NAD}(\mathrm{P}) \mathrm{H}$ oxidasedependent mitogen-activated protein kinase signaling. J Hypertens 2010, 28:806-816.

15. Benicky J, Sánchez-Lemus E, Honda M, Pang T, Orecna M, Wang J, Leng $Y$, Chuang DM, Saavedra JM: Angiotensin II AT(1) receptor blockade ameliorates brain inflammation. Neuropsychopharmacology 2011 36:857-870

16. Kang YM, Zhang ZH, Xue B, Weiss RM, Felder RB: Inhibition of brain proinflammatory cytokine synthesis reduces hypothalamic excitation in rats with ischemia-induced heart failure. Am J Physiol Heart Circ Physiol 2008, 295:H227-H236.

17. Villar-Cheda B, Valenzuela R, Rodriguez-Perez Al, Guerra MJ, LabandeiraGarcia JL: Aging-related changes in the nigral angiotensin system enhances proinflammatory and pro-oxidative markers and 6-OHDAinduced dopaminergic degeneration. Neurobiol Aging 2012, 33:(204)e1-11.

18. Saavedra JM, Sánchez-Lemus E, Benicky J: Blockade of brain angiotensin II AT(1) receptors ameliorates stress, anxiety, brain inflammation and ischemia: Therapeutic implications. Psychoneuroendocrinology 2011, 36:1-18

19. Saavedra JM: Angiotensin II AT(1) Receptor Blockers Ameliorate Inflammatory Stress: A Beneficial Effect for the Treatment of Brain Disorders. Cell Mol Neurobiol, in press.
20. Ando H, Zhou J, Macova M, Imboden H, Saavedra JM: Angiotensin II AT1 receptor blockade reverses pathological hypertrophy and inflammation in brain microvessels of spontaneously hypertensive rats. Stroke 2004, 35:1726-1731.

21. Lou M, Blume A, Zhao Y, Gohlke P, Deuschl G, Herdegen T, Culman J: Sustained blockade of brain AT1 receptors before and after focal cerebral ischemia alleviates neurologic deficits and reduces neuronal injury, apoptosis, and inflammatory responses in the rat. $J$ Cereb Blood Flow Metab 2004, 24:536-547.

22. Sironi L, Gelosa P, Guerrini U, Banfi C, Crippa V, Brioschi M, Gianazza E, Nobil E, Gianella A, de Gasparo M, Tremoli E: Anti-inflammatory effects of AT1 receptor blockade provide end-organ protection in stroke-prone rats independently from blood pressure fall. J Pharmacol Exp Ther 2004, 311:989-995.

23. Iwanami J, Mogi M, Tsukuda K, Min LJ, Sakata A, Jing F, Iwai M, Horiuchi M: Low dose of telmisartan prevents ischemic brain damage with peroxisome proliferator-activated receptor-gamma activation in diabetic mice. J Hypertens 2010, 28:1730-1737

24. Zhou J, Ando H, Macova M, Dou J, Saavedra JM: Angiotensin II AT1 receptor blockade abolishes brain microvascular inflammation and heat shock protein responses in hypertensive rats. J Cereb Blood Flow Metab 2005, 25:878-886.

25. Kobayashi T, Kawamata T, Shibata N, Okada Y, Kobayashi M, Hori T: Angiotensin II type 1 receptor blocker telmisartan reduces cerebral infarct volume and peri-infarct cytosolic phospholipase $A(2)$ level in experimental stroke. J Neurotrauma 2009, 26:2355-2364.

26. Kasahara Y, Taguchi A, Uno H, Nakano A, Nakagomi T, Hirose H, Stern DM, Matsuyama T: Telmisartan suppresses cerebral injury in a murine model of transient focal ischemia. Brain Res 2010, 1340:70-80.

27. Thoene-Reineke C, Rumschüssel K, Schmerbach K, Krikov M, Wengenmayer C, Godes M, Mueller S, Villringer A, Steckelings U, Namsolleck P, Unger T: Prevention and intervention studies with telmisartan, ramipril and their combination in different rat stroke models. PLOS One 2011, 6:e23646.

28. Jung KH, Chu K, Lee ST, Kim SJ, Song EC, Kim EH, Park DK, Sinn DI, Kim JM Kim M, Roh JK: Blockade of AT1 receptor reduces apoptosis, inflammation, and oxidative stress in normotensive rats with intracerebral hemorrhage. J Pharmacol Exp Ther 2007, 322:1051-1058.

29. Lanz TV, Ding Z, Ho PP, Luo J, Agrawal AN, Srinagesh H, Axtell R, Zhang H, Platten M, Wyss-Coray T, Steinman L: Angiotensin II sustains brain inflammation in mice via TGF-beta. J Clin Invest 2010, 120:2782-2794.

30. Mertens $B$, Vanderheyden $P$, Michotte $Y$, Sarre $S$ : The role of the central renin-angiotensin system in Parkinson's disease. J Renin Angiotensin Aldosterone Syst 2010, 11:49-56.

31. Garrido-Gil P, Joglar B, Rodriguez-Perez Al, Guerra MJ, Labandeira-Garcia JL: Involvement of PPAR- $\gamma$ in the neuroprotective and anti-inflammatory effects of angiotensin type 1 receptor inhibition: effects of the receptor antagonist telmisartan and receptor deletion in a mouse MPTP model of Parkinson's disease. J Neuroinflammation 2012, 9:38.

32. Tsukuda K, Mogi M, Iwanami J, Min LJ, Sakata A, Jing F, Iwai M, Horiuchi M: Cognitive deficit in amyloid-beta-injected mice was improved by pretreatment with a low dose of telmisartan partly because of peroxisome proliferator-activated receptor-gamma activation. Hypertension 2009, 54:782-787.

33. Danielyan L, Klein R, Hanson LR, Buadze M, Schwab M, Gleiter CH, Frey WH: Protective effects of intranasal losartan in the APP/PS1 transgenic mouse model of Alzheimer disease. Rejuvenation Res 2010, 13:195-201.

34. Joglar B, Rodriguez-Pallares J, Rodriguez-Perez Al, Rey P, Guerra MJ, Labandeira-Garcia JL: The inflammatory response in the MPTP model of Parkinson's disease is mediated by brain angiotensin: relevance to progression of the disease. J Neurochem 2009, 109:656-669.

35. Rodriguez-Pallares J, Rey P, Parga JA, Muñoz A, Guerra MJ, Labandeira-Garcia $J$ : Brain angiotensin enhances dopaminergic cell death via microglial activation and NADPH-derived ROS. Neurobiol Dis 2008, 31:58-73.

36. Zawada WM, Banninger GP, Thornton J, Marriott B, Cantu D, Rachubinski AL, Das M, Griffin WS, Jones SM: Generation of reactive oxygen species in 1-methyl-4-phenylpyridinium (MPP+) treated dopaminergic neurons occurs as an NADPH oxidase-dependent two-wave cascade. $J$ Neuroinflammation 2011, 8:129.

37. Hoozemans JJ, Veerhuis R, Janssen I, Rozemuller AJ, Eikelenboom P: Interleukin-1beta induced cyclooxygenase 2 expression and 
prostaglandin E2 secretion by human neuroblastoma cells: implications for Alzheimer's disease. Exp Gerontol 2001, 36:559-570.

38. Fiebich BL, Mueksch B, Boehringer M, Hüll M: Interleukin-1 beta induces cyclooxygenase-2 and prostaglandin $\mathrm{E}(2)$ synthesis in human neuroblastoma cells: involvement of p38 mitogen-activated protein kinase and nuclear factor-kappaB. J Neurochem 2000, 75:2020-2028.

39. Benson SC, Pershadsingh HA, Ho Cl, Chittiboyina A, Desai P, Pravenec M, Qi $\mathrm{N}$, Wang J, Avery MA, Kurtz TW: Identification of telmisartan as a unique angiotensin II receptor antagonist with selective PPARgammamodulating activity. Hypertension 2004, 43:993-1002.

40. Erbe DV, Gartrell K, Zhang YL, Suri V, Kirincich SJ, Will S, Perreault M, Wang S, Tobin JF: Molecular activation of PPARgamma by angiotensin II type 1-receptor antagonists. Vascul Pharmacol 2006, 45:154-162.

41. Pang T, Benicky J, Wang J, Orecna M, Sanchez-Lemus E, Saavedra JM: Telmisartan ameliorates lipopolysaccharide-induced innate immune response through PPARY activation in human monocytes. $\int$ Hypertens 2012, 30:87-96

42. Kihara T, Shimohama S, Sawada H, Kimura J, Kume T, Kochiyama H, Maeda T, Akaike A: Nicotinic receptor stimulation protects neurons against betaamyloid toxicity. Ann Neurol 1997, 42:159-163.

43. de Gasparo M, Catt K, Inagami T, Wright JW, Unger T: International union of pharmacology. XXIII. The angiotensin II receptors. Pharmacol Rev 2000, 52:415-472.

44. Mogi M, Li JM, Iwanami J, Min L, Tsukuda K, Iwai M, Horiuchi M: Angiotensin II type-2 receptor stimulation prevents neural damage by transcriptional activation of methyl methanesulfonate sensitive 2 . Hypertension 2006, 48:141-148.

45. Zhao Y, Foryst-Ludwig A, Bruemmer D, Culman J, Bader M, Unger T, Kintscher U: Angiotensin II induces peroxisome proliferator-activated receptor gamma in $\mathrm{PC12W}$ cells via angiotensin type 2 receptor activation. J Neurochem 2005, 94:1395-1401.

46. Im JY, Kim D, Paik SG, Han PL: Cyclooxygenase-2-dependent neuronal death proceeds via superoxide anion generation. Free Radic Biol Med 2006, 41:960-972.

47. Tammariello SP, Quinn MT, Estus S: NADPH oxidase contributes directly to oxidative stress and apoptosis in nerve growth factor-deprived sympathetic neurons. J Neurosci 2000, 20:RC53.

48. Feng L, Xia Y, Garcia GE, Hwang D, Wilson CB: Involvement of reactive oxygen intermediates in cyclooxygenase- 2 expression induced by interleukin-1, tumor necrosis factor-alpha, and lipopolysaccharide. J Clin Invest 1995, 95:1669-1675.

49. Lu Y, Wahl LM: Oxidative stress augments the production of matrix metalloproteinase-1, cyclooxygenase-2, and prostaglandin E2 through enhancement of NF-kappa B activity in lipopolysaccharide-activated human primary monocytes. J Immunol 2005, 175:5423-5429.

50. Stangier J, Su CA, Roth W: Pharmacokinetics of orally and intravenously administered telmisartan in healthy young and elderly volunteers and in hypertensive patients. J Int Med Res 2000, 28:149-167.

51. Li Q, Engelhardt JF: Interleukin-1 beta induction of NFkappaB is partially regulated by $\mathrm{H} 2 \mathrm{O} 2$-mediated activation of NFkappaB-inducing kinase. $J$ Biol Chem 2006, 281:1495-1505.

52. Chen H, Kim GS, Okami N, Narasimhan P, Chan PH: NADPH oxidase is involved in post-ischemic brain inflammation. Neurobiol Dis 2011, 42:341-348

53. Cianchetti S, Del Fiorentino A, Colognato R, Di Stefano R, Franzoni F, Pedrinelli R: Anti-inflammatory and anti-oxidant properties of telmisartan in cultured human umbilical vein endothelial cells. Atherosclerosis 2008, 198:22-28.

54. Hancock JT, Jones OT: The inhibition by diphenyleneiodonium and its analogues of superoxide generation by macrophages. Biochem J 1987, 242:103-107.

55. Stuehr DJ, Fasehun OA, Kwon NS, Gross SS, Gonzalez JA, Levi R, Nathan CF: Inhibition of macrophage and endothelial cell nitric oxide synthase by diphenyleneiodonium and its analogs. FASEB J 1991, 5:98-103.

56. Yamamoto E, Tamamaki N, Nakamura T, Kataoka K, Tokutomi Y, Dong YF, Fukuda M, Matsuba S, Ogawa H, Kim-Mitsuyama S: Excess salt causes cerebral neuronal apoptosis and inflammation in stroke-prone hypertensive rats through angiotensin II-induced NADPH oxidase activation. Stroke 2008, 39:3049-3056.

57. Pelisch N, Hosomi N, Ueno M, Nakano D, Hitomi H, Mogi M, Shimada K, Kobori H, Horiuchi M, Sakamoto H, Matsumoto M, Kohno M, Nishiyama A:
Blockade of AT1 receptors protects the blood-brain barrier and improves cognition in Dahl salt-sensitive hypertensive rats. Am J Hypertens 2011, 24:362-368.

58. Moolwaney AS, Igwe OJ: Regulation of the cyclooxygenase-2 system by interleukin-1 beta through mitogen-activated protein kinase signaling pathways: a comparative study of human neuroglioma and neuroblastoma cells. Brain Res Mol Brain Res 2005, 137:202-212

59. Bourke E, Moynagh PN: Antiinflammatory effects of glucocorticoids in brain cells, independent of NF-kappa B. J Immunol 1999, 163:2113-2119.

60. Petrova TV, Akama KT, Van Eldik LJ: Cyclopentenone prostaglandins suppress activation of microglia: down-regulation of inducible nitric-oxide synthase by 15-deoxy-Delta12,14-prostaglandin J2. Proc Natl Acad Sci U S A 1999, 96:4668-4673.

61. Bernardo A, Levi G, Minghetti L: Role of the peroxisome proliferatoractivated receptor-gamma (PPAR-gamma) and its natural ligand 15deoxy-Delta12, 14-prostaglandin $\mathrm{J} 2$ in the regulation of microglial functions. Eur I Neurosci 2000, 12:2215-2223.

62. Combs CK, Johnson DE, Karlo JC, Cannady SB, Landreth GE: Inflammatory mechanisms in Alzheimer's disease: inhibition of beta-amyloidstimulated proinflammatory responses and neurotoxicity by PPARgamma agonists. J Neurosci 2000, 20:558-567.

63. Swanson CR, Joers V, Bondarenko V, Brunner $K$, Simmons HA, Ziegler TE, Kemnitz JW, Johnson JA, Emborg ME: The PPAR- $\gamma$ agonist pioglitazone modulates inflammation and induces neuroprotection in parkinsonian monkeys. J Neuroinflammation 2011, 8:91.

64. An J, Nakajima T, Kuba K, Kimura A: Losartan inhibits LPS-induced inflammatory signaling through a PPARgamma-dependent mechanism in human THP-1 macrophages. Hypertens Res 2010, 33:831-835.

65. Janke J, Schupp M, Engeli S, Gorzelniak K, Boschmann M, Sauma L, Nystrom FH, Jordan J, Luft FC, Sharma AM: Angiotensin type 1 receptor antagonists induce human in-vitro adipogenesis through peroxisome proliferatoractivated receptor-gamma activation. J Hypertens 2006, 24:1809-1816.

66. Zorad S, Dou JT, Benicky J, Hutanu D, Tybitanclova K, Zhou J, Saavedra JM: Long-term angiotensin II AT1 receptor inhibition produces adipose tissue hypotrophy accompanied by increased expression of adiponectin and PPARgamma. Eur J Pharmacol 2006, 552:112-122.

67. Subramanian V, Golledge J, Heywood EB, Bruemmer D, Daugherty A: Regulation of peroxisome proliferator-activated receptor- $\gamma$ by angiotensin II via transforming growth factor- $\beta 1$-activated p38 mitogen-activated protein kinase in aortic smooth muscle cells. Arterioscler Thromb Vasc Biol 2012 32:397-405.

68. Tham DM, Martin-McNulty B, Wang YX, Wilson DW, Vergona R, Sullivan ME, Dole W, Rutledge JC: Angiotensin II is associated with activation of NFkappaB-mediated genes and downregulation of PPARs. Physiol Genomics 2002, 11:21-30.

69. Yatabe J, Sanada H, Yatabe MS, Hashimoto S, Yoneda M, Felder RA, Jose PA, Watanabe T: Angiotensin II type 1 receptor blocker attenuates the activation of ERK and NADPH oxidase by mechanical strain in mesangial cells in the absence of angiotensin II. Am J Physiol Renal Physiol 2009, 296: F1052-F1060.

70. Yasuda N, Akazawa H, Ito K, Shimizu I, Kudo-Sakamoto Y, Yabumoto C, Yano M, Yamamoto R, Ozasa Y, Minamino T, Naito AT, Oka T, Shiojima I, Tamura K, Umemura S, Nemer M, Komuro I: Agonist-independent constitutive activity of angiotensin II receptor promotes cardiac remodeling in mice. Hypertension 2012, 59:627-633.

71. Hoozemans JJ, Rozemuller AJ, Janssen I, De Groot CJ, Veerhuis R, Eikelenboom P: Cyclooxygenase expression in microglia and neurons in Alzheimer's disease and control brain. Acta Neuropathol 2001, 101:2-8.

72. Montine TJ, Sidell KR, Crews BC, Markesbery WR, Marnett $L$, Roberts $L$, Morrow JD: Elevated CSF prostaglandin E2 levels in patients with probable AD. Neurology 1999, 53:1495-1498.

73. Griffin DE, Wesselingh SL, MCArthur JC: Elevated central nervous system prostaglandins in human immunodeficiency virus-associated dementia. Ann Neurol 1994, 35:592-597.

74. Hoozemans JJ, van Haastert ES, Veerhuis R, Arendt T, Scheper W, Eikelenboom P, Rozemuller AJ: Maximal COX-2 and ppRb expression in neurons occurs during early Braak stages prior to the maximal activation of astrocytes and microglia in Alzheimer's disease. I Neuroinflammation 2005, 2:27. 
75. Davies NM, Kehoe PG, Ben-Shlomo Y, Martin RM: Associations of anti-hypertensive treatments with Alzheimer's disease, vascular dementia, and other dementias. J Alzheimers Dis 2011, 26:699-708.

76. Li NC, Lee A, Whitmer RA, Kivipelto M, Lawler E, Kazis LE, Wolozin B: Use of Angiotensin receptor blockers and risk of dementia in a predominantly male population: prospective cohort analysis. BMJ 2010, 340:b5465.

doi:10.1186/1742-2094-9-102

Cite this article as: Pang et al:: Telmisartan directly ameliorates the neuronal inflammatory response to IL-1 $\beta$ partly through the JNK/c-Jun and NADPH oxidase pathways. Journal of Neuroinflammation 2012 9:102.

\section{Submit your next manuscript to BioMed Central and take full advantage of:}

- Convenient online submission

- Thorough peer review

- No space constraints or color figure charges

- Immediate publication on acceptance

- Inclusion in PubMed, CAS, Scopus and Google Scholar

- Research which is freely available for redistribution 